\title{
Dynamic lateral response of suction caissons
}

\author{
Latini, Chiara; Zania, Varvara
}

Published in:

Soil Dynamics and Earthquake Engineering

Link to article, DOI:

10.1016/j.soildyn.2017.05.020

Publication date:

2017

Document Version

Peer reviewed version

Link back to DTU Orbit

Citation (APA):

Latini, C., \& Zania, V. (2017). Dynamic lateral response of suction caissons. Soil Dynamics and Earthquake Engineering, 100, 59-71. https://doi.org/10.1016/j.soildyn.2017.05.020

\section{General rights}

Copyright and moral rights for the publications made accessible in the public portal are retained by the authors and/or other copyright owners and it is a condition of accessing publications that users recognise and abide by the legal requirements associated with these rights.

- Users may download and print one copy of any publication from the public portal for the purpose of private study or research.

- You may not further distribute the material or use it for any profit-making activity or commercial gain

- You may freely distribute the URL identifying the publication in the public portal

If you believe that this document breaches copyright please contact us providing details, and we will remove access to the work immediately and investigate your claim 


\title{
DYNAMIC LATERAL RESPONSE OF SUCTION CAISSONS
}

\author{
C. Latini \\ PhD Student \\ Civil Engineering Department, Technical University of Denmark, Denmark \\ e-mail: chila@byg.dtu.dk \\ V. Zania \\ Associate Professor \\ Civil Engineering Department, Technical University of Denmark, Denmark \\ e-mail: vaza@byg.dtu.dk
}




\section{ABSTRACT}

Deeper water installations of offshore wind turbines may be supported by jacket structures. This study investigates the dynamic response of suction caissons for jackets by analyzing 3D finite element models in the frequency domain. The numerical modelling was firstly validated by analytical solutions for pile foundations. Groups of crucial dimensionless parameters related to the soil profile and the foundation geometry are identified and their effects on the response of suction caissons are studied. Static stiffness coefficients are presented in a form of mathematical formulas obtained by fitting the numerical results, pertaining foundations with different slenderness ratios and embedded in different soil profiles.

Sensitivity of the dynamic impedances of suction caissons on the skirt length was showed in this study. Moreover, the results for the suction caissons indicated that the overall dynamic response is profoundly affected by the relative thickness of the soil layer and by the variation of soil stiffness with depth.

Keywords: soil - structure - interaction, dynamic stiffness, damping, floating foundations, suction caissons, numerical modelling, site effects

\section{Introduction}

The offshore wind market is developing towards wind farms with higher capacity generators and in deeper waters, which places new demands on current offshore design procedures. So far the selection of the type of support structures for offshore wind turbines are determined by the water depth. In shallow waters, monopiles and monopod suction buckets are mostly utilized, while jacket structures with piles or with suction caissons would be the design configuration for deeper waters following the designs traditionally used by the oil and gas industry [1]. In the work of Houlsby et al. [2] the applicability of suction caissons as offshore wind turbine foundations is suggested for suitable soil conditions and particularly for deeper waters, with a water depth of up to about $40 \mathrm{~m}$. Suction caissons are skirted shallow foundations (with a slenderness ratio $H_{p} / d$ lower than 4 , where $H_{p}$ and $d$ are the foundation height and diameter, respectively) that are first installed using self-weight and then by pumping out the water trapped within the skirts [3]. In contrast to driven piles, heavy duty equipment 
is not required for suction caisson installation. Moreover the noise disturbance of the marine life is diminished, making this type of foundation an attractive alternative for deep water installations.

In the design of offshore wind support structures one of the critical issues is the fatigue that occurs due to the combination of wind, wave and earthquake loading. In addition, the potential of structural resonance with the dynamic forces of wind loading would result in large amplitude stresses and accelerated fatigue. Therefore, it is fundamental to accurately assess the resonance frequencies of the wind turbine structure in order to ensure that the first resonance frequency of the wind turbines does not coincide with the excitation frequencies of the rotor system [4]. Furthermore, the overall damping of the structure reduces greatly fatigue damage, since the amplitude of vibrations at resonance is inversely proportional to the damping ratios [5]. Wolf [6] showed that both the eigenfrequency and the damping of any structure subjected to dynamic load are modified due to the soil-foundation interaction. Hence the dynamic stiffness and damping of the soil-foundation system should be included in the estimation of the natural vibration characteristics of any offshore wind turbine as indicated by several studies $[7,8,9]$.

In the literature the problem of the dynamic soil-pile interaction has been extensively investigated. Indeed, there are several analytical and numerical studies on the estimation of the dynamic impedances of the horizontal vibration of single piles. Considering only those for a linear elastic soil layer they can be classified as follows:

a) analytical continuum solutions for end bearing piles $[10,11,12]$, where the soil was modelled as a homogeneous layer with hysteretic material damping;

b) Winkler type analytical solutions $[13,14,15]$, where the supporting soil was substituted by a bed of independent elastic springs overlying a rigid bedrock. For dynamic problems Novak [13] recommended the use of Winkler foundation coefficients based on Baranov's equation for the in-plane and out-plane vibration of a disk. An improved model incorporating in the analysis the normal and 
shear stresses acting on the upper and lower faces of a horizontal soil element by integrating the governing equations over the thickness of the soil layer was developed by Mylonakis [15];

c) numerical continuum finite element solutions $[16,17,18,19,20]$, where the pile was modelled as series of regular beam segments with a rigid cross section and the soil was considered as an elastic continuum.

Very few studies investigating the dynamic response of floating piles either numerically [20] or analytically $[21,22,23]$ are available in the literature. It was shown that the stiffness and the thickness of the soil layer play a fundamental role in the estimation of the dynamic impedances of floating piles. In addition, there is a significant number of studies analysing the dynamic lateral response of single piles or pile groups embedded in a homogeneous half space, where numerical methods (e.g. finite element $[24,25,26]$, and/or boundary element methods [27,28]) or analytical elastodynamic solutions $[29,30,31]$ were employed.

In the case of suction caissons the vast majority of research studies has been focused on the analysis of the load capacity under the action of combined vertical, horizontal and moment loading [32,33,34]. Moreover, the seismic response of suction caisson foundations was also investigated [35]. However, the dynamic response of suction caissons has received less attention [36,37]. In the work of Liingaard [36] the dynamic stiffness coefficients were determined, considering linear viscoelastic soil and modelling the suction caisson using a coupled BE/FE model in homogeneous halfspace comparing the obtained results with analytical solutions for surface foundations. In that study it was shown that the dynamic impedances pattern suggested by the analytical solution for surface foundations did not resemble the one obtained from the numerical model for $H_{p} / d>0.25$, while it was in good agreement with the outcomes of the BE/FE model for the case of surface footing. Moreover, Liingaard [36] highlighted the high dependency of the horizontal and rocking component of the stiffness on Poisson's ratio and examined the influence of the skirt flexibility on the dynamic response of caisson foundations embedded in a homogeneous soil layer. It was observed that the increase of the dynamic 
impedances of suction caisson in the frequency domain is more pronounced when the slenderness ratio increases $\left(H_{p} / d=0.25-1\right)$.

The current study aims at investigating the dynamic response characteristics of suction caissons, to formulate a basis for understanding the natural vibrations characteristics of foundations for jacket structures. The literature study has shown that some aspects of the dynamic behavior of this type of foundations has not been investigated so far (e.g. site effects). Therefore, a numerical study was performed and the dynamic impedances of suction caissons subjected to lateral loading were estimated. Experimental studies [38] have shown that multi-caisson supported wind turbine structures are mainly influenced by the vertical component of dynamic stiffness, which is not addressed in the present study because of space limitations...Due to the absence in the literature of analytical solutions on the dynamic response of suction caissons embedded in a soil layer on a rigid bedrock, the numerical modelling approach was validated with the rigorous analytical solution of dynamic vibration of soil-end bearing pile [10] and soil-floating pile [22]. The effect of the major parameters affecting the dynamic response of suction caissons embedded in a soil stratum on a rigid bedrock was investigated. The validated numerical methodology was adopted to perform the parametric study, while the rationale behind the selection of the parameters was to highlight the role of the nondimensional parameters of the problem such as the slenderness ratio $H_{p} / d$, the relative stiffness $E_{p} / E_{s}$ and the relative thickness of the soil layer $H_{s} / d$. Furthermore, the dynamic response of suction caissons was analysed for different soil profiles, considering a stiffness distribution with depth.

\section{Methodology}

A series of 3D finite element models in the commercial software ABAQUS [39] were deployed to analyze the dynamic impedances of suction caissons. The numerical models accounted for the following hypotheses: 1) linear elastic isotropic behaviour of the foundation; 2) linear viscoelastic 
isotropic behaviour of soil with hysteretic type damping (frequency independent) and 3) perfect contact between the foundation and the soil during the analysis.

Only half of the foundation and the surrounding soil were taken into account in the model, as a result of the symmetry of the problem, see Figure 1. Two different foundation modelling approaches were used: 1) shell cylinder, where the foundation was discretized by shell elements (S4) and 2) equivalent solid cylinder, for which equivalent material properties were applied to $3 \mathrm{D}$ continuum elements (C3D8) in order to match the bending stiffness of the hollow cylinder and the inner soil. The far field soil response $\left(\mathrm{L}_{\mathrm{inf}}=180 \mathrm{~m}\right)$ was modelled using infinite elements to avoid spurious reflections. The near field soil domain $\left(\mathrm{L}_{\mathrm{fin}}=180 \mathrm{~m}\right)$ was discretized by 8 -node $3 \mathrm{D}$ continuum elements (C3D8). The soil and the foundation lateral surfaces were bonded together to satisfy displacement compatibility. The steady state linearized response of the model subjected to harmonic excitation in the frequency domain was obtained. The dynamic impedances $K_{S u}, K_{S \theta}, K_{M u}$ and $K_{M \theta}$ at the level of the foundation head were then calculated as shear forces, $S$, and moments, $M$, when the head of the foundation was subjected to unit displacement, $u$, and rotation, $\theta$. The mesh size was set small enough to capture the stress wave accurately even at high frequency range. A mesh size of at least 10 to 20 elements per wave length for the frequency range of interest was used, including up to the third eigenfrequency of the soil layer $\alpha_{0}=5 / 2 \pi$. Note that $\alpha_{0}$ is a dimensionless frequency related to the eigenfrequency of the soil layer, since it is given as the product of the wave number and the thickness of the soil layer.

$\alpha_{0}=\frac{\omega H_{s}}{V_{s}}$

where $\omega(\mathrm{rad} / \mathrm{sec}), H_{s}(\mathrm{~m})$ and $V_{s}(\mathrm{~m} / \mathrm{s})$ are respectively the frequency, the thickness and the shear wave velocity of the soil layer.

In addition, the aspect ratios of elements used in the mesh ranged from 1.6 near the foundation head to about 8 near the boundaries of the finite element mesh. A view of the model with the mesh refinement is shown in Figure 1. 
From the state of the art it is deduced that the dynamic behaviour of suction caissons embedded in a halfspace was already investigated, see [36]. Hence this study focused on the case of a soil layer overlying a rigid bedrock surface. 3D numerical models were first established to validate the numerical methodology against published analytical solutions of the dynamic response of end bearing (Figure 2A) and floating piles (Figure 2B). Consequently, the validation of the numerical methodology was performed by considering a small diameter $\left(d=2 r_{0}=1 \mathrm{~m}\right)$ hollow, flexible, steel pile of thickness $t=d / 50$, height $H_{p}=10 \mathrm{~m}$ embedded in a homogeneous soil layer with thickness $\mathrm{H}_{\mathrm{s}}=10 \mathrm{~m}$ (Figure 2A), 30m (Figure 2B) and constant profile of shear wave velocity $\left(V_{s}=250 \mathrm{~m} / \mathrm{s}\right)$, thickness $\left(t=r_{0} / 50\right)$, hysteretic material damping $(\zeta=5 \%$, see [40]) and Poisson's ratio $(v=0.35)$ over a wide frequency range including at least the third eigenfrequency of the soil layer $\left(\alpha_{0}=5 / 2 \pi\right)$.

The fact that the geometry of suction caissons differs from that of piles, due to the hollow section and the presence of the cap, could introduce different mechanisms of wave propagation, e.g. due to the contact of the cap with the soil. This was investigated in a former study by Latini et al. [37], which showed that the solid cylinder and the suction caisson does not exhibit different dynamic behaviour. Moreover the analytical solution for flexible floating piles [22] cannot capture the response of suction caissons, possibly due to the negligence of the vertical displacements and the effect of the smaller slenderness ratio in the generation of surface waves. Additionally, it was observed that the presence of the cap did not alter the dynamic response of the suction caissons. Hereafter, the geometry of the caisson comprising of a hollow cylinder (skirt) and a cap was modelled with shell elements (S4).

\section{Validation with analytical solutions}

First, the numerical model was validated with the rigorous analytical solution for horizontally vibrating end bearing piles proposed by Novak and Nogami [10] for the case of soil profile in Figure 2A. The static stiffness coefficients of the numerical model were calculated at low frequencies and 
presented in Table 1, along with the corresponding values obtained by applying the analytical solution. A discrepancy of $12.5 \%, 30.5 \%$ and $2.3 \%$ was obtained for the horizontal, coupling and rocking terms, respectively. This difference can be motivated by the fact that the analytical solution does not taken into account the vertical displacements in the estimation of the impedances of the soilpile system with the coupling component being mainly influenced. In Figure $3 \mathrm{a}$ only the real $\left(K_{S u}\right)$ and the imaginary $\left(2 \zeta_{S u}\right)$ part of the translational dynamic impedances are shown. However the conclusions drawn here are valid also for the other two components $K_{S \theta}$, and $K_{M \theta}$. A reduction of stiffness at the $1^{\text {st }}$ and $2^{\text {nd }}$ eigenfrequency of the soil layer $\left(\alpha_{0}=1 / 2 \pi\right.$ and $3 / 2 \pi$, accordingly $)$ is observed. The numerical model exhibited an extra drop in stiffness attained around the $1^{\text {st }}$ vertical resonance $\alpha_{0}=1 / 2 \pi \eta$, where $\eta=\sqrt{2(1-v) /(1-2 v)}$, which was less marked for the case of the cross coupling and rocking components. This can be explained by the fact that in the analytical formulation vertical displacements are disregarded. The generated damping is associated to the imaginary part of the dynamic coefficient of the dynamic impedances, due to the soil-pile interaction. Radiation damping was developed after the $1^{\text {st }}$ eigenfrequency of the soil layer for all the components. Step increase of the damping ratio can be roughly approximated by linear function with the frequency, which is then modelled by viscous type damping. A slight increase in the slope of the damping ratio after each eigenfrequency of the soil layer is observed. In addition, the results of the shell pile and the equivalent solid pile model matched perfectly in the frequency interval investigated. The numerical results seemed to be in good agreement with those of the analytical solution, even if a slight discrepancy was recorded for frequencies higher than $\alpha_{0}=4$. In Figure $3 \mathrm{~b}$ the deformed shape of the pile is plotted as a function of the depth at the three first eigenfrequencies of the soil layer and the numerical trend resembled the one suggested by the analytical formulation.

For the floating pile, the numerical model was validated by deploying the analytical solution of Latini et al. [22]. The static stiffness coefficients were estimated and compared with those attained respectively by the analytical solution of Latini et al. [22]. The results are given in Table 1 . The 
deviation in percentage between the results of the analytical formulation of Latini et al. [22] and the numerical model were $2.5 \%, 24.5 \%$ and $9.7 \%$. It is evident that the numerical model achieved similar values to those obtained by using the analytical formulation, which slightly overestimated the lateral and coupling coefficients. In Figure 4 the real $\left(K_{S u}, K_{S \theta}\right.$, and $\left.K_{M \theta}\right)$ and the imaginary $\left(2 \zeta_{S u}, 2 \zeta_{S \theta}\right.$, and $\left.2 \zeta_{M \theta}\right)$ parts of the dynamic impedances are presented. Note that the numerical model was established considering equivalent solid pile in order to be consistent with the assumption of solid pile cross section of the analytical formulation. Slightly scattered results were observed comparing the analytical solution of Latini et al. [22] and the numerical model after the $2^{\text {nd }}$ horizontal eigenfrequency of the soil layer. The damping ratio obtained from the analytical solution was overestimated concerning the cross coupling stiffness term for frequencies smaller than the $1^{\text {st }}$ horizontal eigenfrequency of the soil layer, while an increased variation of the damping coefficient was observed after the $1^{\text {st }}$ horizontal resonance frequency of the soil layer for the rocking component.

In Figure 5 the deformed shape of the pile is illustrated with respect the depth at the three first eigenfrequencies of the soil layer. The modal shapes obtained from the numerical model match almost perfectly those of the analytical solution, except only from the $3^{\text {rd }}$ eigenfrequency where the analytical solution underestimates the deflection.

In this section the two numerical models were validated against analytical solutions and the comparison of Figures 3 and 4 demonstrate that floating piles exert a different behavior than end bearing piles.

\section{Parametric study}

The role of key dimensionless parameters such as the stiffness ratio $E_{p} / E_{s}$, the slenderness ratio $H_{p} / d$ and the pile flexibility factor $K_{r}$ on the response of end bearing piles has been illustrated previously ([41] and [42]). Moreover, studies on the dynamic response of floating piles ([21], [22]) highlighted the influence of the thickness of the soil layer on the dynamic impedances of this type of foundations. 
The dependency of dynamic stiffness coefficients on the dimensionless parameter $H_{s} / d$, defined as the relative thickness of the soil layer, was pointed out only for the case of surface footings in the work of Gazetas [43]. Since these studies have been investigating piles with slenderness ratio more than 10 or surface footings, the relevance of these findings to suction caissons and the effects of the abovementioned dimensionless parameters to the dynamic soil suction caisson interaction is hereafter investigated. The cases selected in the current analysis and the dimensionless parameters are listed in Table 2, while the rationale behind their selection was to investigate foundations with different skirt length and diameter to study the dynamic response of suction caissons for different slenderness ratios $\left(H_{p} / d\right)$ and site conditions $\left(E_{p} / E_{s}, H_{s} / d\right)$.

Three soil profiles were considered, each with a different distribution of $E_{s}(z)$ with depth as reported in Figure 6. In the numerical analysis the shear wave velocity of the soil layer was assumed to increase with depth according to the following expression [44]:

$V_{s}(z)=V_{H}\left[b+(1-b) \frac{z}{H_{s}}\right]^{n}$

where $\mathrm{b}$ is given as a function of the shear wave velocity at the surface $\left(V_{0}\right)$ and base $\left(V_{H}\right)$ of the inhomogeneous soil layer $\left(b=\left(V_{0} / V_{H}\right)^{1 / n}\right), \mathrm{n}$ is a dimensionless inhomogeneity factor $(n=0 \div 1)$ and $z$ represents the depth measured from the ground surface. Profile A has constant shear wave velocity $\left(V_{S}=250,300,400,500 \mathrm{~m} / \mathrm{s}-\right.$ cases $\left.5-18\right)$, which is typical for overconsolidated clay deposits. The parameter $n$ was set equal to 0.25 for profile $B$, representing uniform medium-dense sand deposits, see cases 19- 21 . In profile $\mathrm{C}, E_{s}(z)$ is proportional to depth and $n=0.5$ was taken into account in order to investigate normally consolidated clay strata (cases 22-24).

Shear wave velocity ratio $V_{0} / V_{H}$ (at the surface and the base of the inhomogeneous layer) was considered equal to 0.01 and 0.1 respectively for the soil models $\mathrm{B}$ and $\mathrm{C}$ to account for strong gradient in shear wave velocity. And the reference base shear wave velocity was $500 \mathrm{~m} / \mathrm{s}$ in order to model a continuously inhomogeneous viscoelastic soil medium of thickness $\mathrm{H}_{\mathrm{s}}$ over rigid bedrock. The hysteretic material damping $(\zeta=5 \%)$ and Poisson's ratio $(v=0.35)$ were identical for all the 
examined cases. These three models may adequately represent the dynamic characteristics of a fairly wide range of real soil profiles.

\subsection{Static stiffness}

The effect of the slenderness ratio on the static stiffness components of suction caisson foundations was herein analysed. In the literature there are several approximate closed-form solutions expressions for the static stiffness terms of piles $[19,41,42]$. For large slenderness ratio $\left(H_{p} / d \geq 10\right)$, Randolph [42] suggested a set of stiffness expressions depending on the stiffness ratio $\left(E_{p} / G^{*}\right)$, where $G^{*}=G$ $\left(1+\frac{3}{4} v\right)$, in order to predict accurately the response of flexible foundations. Nevertheless, for smaller slenderness ratio - like in the case of suction caissons - the deformation mode changes and the $H_{p} / d$ affects the static stiffness. Carter and Kulhawy [45] accounted for this effect by suggesting expressions based on the slenderness ratio for rigid shafts. Another approach would be to consider the stiffness of surface foundations [46], while Gelagoti et al. [47] modified the previously suggested expressions for embedded foundations [43] by translating the load reference point at the top of the foundation.

In this work the closed-form expressions suggested by Randolph [42] for flexible piles were modified by accounting also the contribution of the slenderness ratio, in order to provide closer approximations of the static stiffness components of suction caissons. The results of the numerical analysis were fitted with the exponential functions shown in Figure 7a. It was observed that the curve fitting is better for $H_{p} / d>0.5$. In addition, the numerical results of the static stiffness components for the suction caisson case were compared respectively with previously published expressions $[46,47,48]$. The static stiffness components obtained by the mathematical expressions were divided by the corresponding numerical ones and they are presented with respect to the slenderness ratio in Figure $7 \mathrm{~b}$. It may be observed that the expressions from Wolf and Deeks [46] slightly overestimate all the static 
components up to $H_{p} / d=0.5$ for $E_{p} / E_{s}=60$, while the opposite is observed for the expressions of Gelagoti et al. [47] for the horizontal and coupling terms. In addition, the calculated stiffness coefficients using the expressions by Shadlou and Bhattacharya [48] which were developed for higher $H_{p} / d$ values are very similar to the ones obtained by Gelagoti et al. [47]. The deviation of the previous studies $[46,47,48]$ becomes more apparent for higher $H_{p} / d$ values.

Thus, displacements of suction caissons can be expressed by these simple mathematical equations obtained by fitting the numerical data:

$$
\begin{aligned}
& u=0.56\left(\frac{S}{G^{*} d}\right)\left(\frac{E_{p}}{G^{*}}\right)-0.18\left(\frac{H_{p}}{d}\right)-0.156+7.10\left(\frac{M}{G^{*} d^{2}}\right)\left(\frac{E_{p}}{G^{*}}\right)-0.52\left(\frac{H_{p}}{d}\right)-0.656 \\
& \theta=7.10\left(\frac{S}{G^{*} d^{2}}\right)\left(\frac{E_{p}}{G^{*}}\right)-0.52\left(\frac{H_{p}}{d}\right)-0.656+2.29\left(\frac{M}{G^{*} d^{3}}\right)\left(\frac{E_{p}}{G^{*}}\right)-0.40\left(\frac{H_{p}}{d}\right)-0.728
\end{aligned}
$$

The new suggested expressions reduce substantially the scatter and provide a better approximation of static stiffness components of suction caissons.

\subsection{Dynamic impedances}

\subsubsection{Effect of the slenderness ratio}

Figure 8 illustrates the real $\left(K_{S u}, K_{S \theta}\right.$, and $\left.K_{M \theta}\right)$ and the imaginary $\left(2 \zeta_{S u}, 2 \zeta_{S \theta}\right.$, and $\left.2 \zeta_{M \theta}\right)$ parts of the dynamic impedances for several values of the slenderness ratio $H_{p} / d$ (cases 2-6, in Table 2) by varying the skirt length, while the same soil profile is considered. Note that all investigated cases resemble rigid foundation response according to the flexibility criterion suggested by Poulos and Davis [41]. Overall the pattern of the stiffness variation with frequency is influenced by the slenderness ratio after the $1^{\text {st }}$ vertical eigenfrequency of the soil layer. It was observed that the reduction in stiffness attained at the $1^{\text {st }}$ horizontal eigefrequency $\left(\alpha_{0}=\pi / 2\right)$ of the soil layer became less marked as the slenderness ratio decreased. The decrease of the dynamic stiffness components of suction caissons with decreasing slenderness ratio at higher frequency range, has been previously observed for the case of suction caisson in homogeneous halfspace [36]. Regarding the higher frequency range (larger than $\mathrm{a}_{0}>3$ ) a 
distinctively different behaviour is observed for $H_{p} / d>1$, where the dynamic stiffness appears to increase attaining values even higher than the static ones especially for the coupling and rocking term. This can be explained by the effect of the coupling between the horizontal and the rotational degrees of freedom, which appears more evident with increasing slenderness ratio $\left(\mathrm{H}_{\mathrm{p}} / \mathrm{d}>1\right)$, as more rotation and less lateral governs the response. Results of the displacement vectors in the higher frequency range showed a kind of a scoop-slide mechanism, which resembled the failure mechanism of suction caissons embedded in clay as observed in the work of Randolph and House [33]. On the contrary, in the case of suction caissons with $\mathrm{H}_{\mathrm{p}} / \mathrm{d}<1$ horizontal vibrations due to the interaction between the foundation skirt and the soil layer are mainly transmitted to the surrounding soil at shallow depths, enhancing the lateral response of the foundation. Indeed, it was noticed that the contribution of the vertical displacement to the displacement resultant is negligible along the whole foundation skirt.

The effect of the skirt length on the damping is not consistent for all the damping components, while $H_{p} / d=0.25$ gives consistently the lowest damping ratios of all the examined cases. The pattern of the damping variation with respect to the normalised frequency is not affected by the slenderness ratio; it is still observed an increase of the slope after each eigenfrequency of the soil layer. There is indication that the increase of $H_{p} / d$ would result to higher damping ratio, especially for the horizontal component and frequency range lower than the $2^{\text {nd }}$ eigenfrequency of the soil layer.

\subsubsection{Effect of the soil thickness}

In order to address the effect of the thickness of the soil layer, first it is prudent to figure out the adequate corresponding dimensionless parameter. This was investigated by keeping all dimensionless parameters constant and changing only the diameter and the soil layer thickness, while referring to the same slenderness ratio and relative thickness of the soil layer $\left(H_{s} / d\right)$ in the dynamic analysis of suction caissons. The results of the real $\left(K_{S u}, K_{S \theta}\right.$, and $\left.K_{M \theta}\right)$ and the imaginary $\left(2 \zeta_{S u}, 2 \zeta_{S \theta}\right.$, and $\left.2 \zeta_{M \theta}\right)$ parts of the dynamic impedances (cases 7-10, in Table 2) are reported in Figure 9. It appears that the relative 
thickness of the soil layer $H_{s} / d$ is an adequate nondimensional parameter in the estimation of the dynamic impedances of suction caissons, since the sensitivity of the dynamic stiffness coefficients on the variation of the diameter was found hardly noticeable for the frequency range investigated. Moreover, this conclusion is valid for both the minimum and maximum slenderness ratio in this study. The effect of $H_{s} / d$ ratio on the frequency variation of the dynamic stiffness and damping coefficients is depicted in Figure 10 (cases 8, $10-12$, in Table 2). The trend of the dynamic impedances appears to be influenced by the variation of the dimensionless parameter $H_{s} / d$ in the frequency range considered. First the drop of stiffness exhibited at the $1^{\text {st }}$ resonance, when referring to same slenderness ratio $H_{p} / d$, becomes more distinct as the relative thickness of the layer $H_{s} / d$ decreased. This can be explained by the fact that the longer the path the propagating waves travel, the more the stress waves are attenuated with the distance and therefore the decay of the dynamic impedances is less appreciable. The decrease of the dynamic impedances with the smaller $\mathrm{H}_{\mathrm{s}} / \mathrm{d}$ has been previously observed for the dynamic response of surface footing [43].

A small influence of the relative thickness of the soil medium on the variation of the rocking component is recorded, while the translational and coupling coefficients seemed to be more affected by the dimensionless parameter $H_{s} / d$.

A possible explanation of this trend is that the coupling between the horizontal and the rotational degrees of freedom is enhanced by the nondimensional parameter $H_{s} / d$, since the suction caisson foundation experienced higher rotation at the tip for frequencies greater than the $1^{\text {st }}$ vertical resonance when the relative thickness of the soil layer assumed lower values.

In regards to the imaginary components, it appears that the step-linear increasing pattern of the damping ratio at higher frequencies is characterized by higher slope as the relative thickness of the soil layer decreases. This increase of the variation of the damping ratio observed for smaller values of soil profile thickness is related to the concurrent decrease of the dynamic component of the stiffness coefficients. On the other hand, the viscous damping coefficients in the frequency range studied 
increase by increasing $H_{s} / d$, in agreement with the fact that more energy is dissipated as the propagating waves travel at longer distance.

Concluding, the numerical outcomes show that the relative thickness of the soil layer $H_{s} / d$ is a fundamental dimensionless parameter for understanding the dynamic response of floating foundations.

\subsubsection{Effect of the soil stiffness}

Figure 11 shows the real $\left(K_{S u}, K_{S \theta}\right.$, and $\left.K_{M \theta}\right)$ and the imaginary $\left(2 \zeta_{S u}, 2 \zeta_{S \theta}\right.$, and $\left.2 \zeta_{M \theta}\right)$ part of the dynamic impedances varying the stiffness of the homogeneous soil layer (profile A) respectively for $H_{p} / d=2$ (cases $2,13,14$ and 15). The increase of the shear wave velocity of the soil layer affects marginally the dynamic impedances, which are increased for the entire frequency range. In addition, the rocking term appears fairly constant with frequency particularly when it is higher than the $1^{\text {st }}$ eigenfrequency of the soil medium, and when the factor $\mathrm{K}_{\mathrm{r}}$ decreased. The damping ratios are slighlty decreased for increased soil stiffness. The effect of the soil stiffness for profile A was also investigated for small slenderness ratio $\left(H_{p} / d=0.25\right)$. The results, which are not presented here due to space limitations, indicated that at small skirt lengths the dynamic response of the caisson is insensitive to the soil stiffness at homogeneous soil layers. This can be motived by the fact that the horizontal vibrations are transmitted to the surrounding soil at relatively larger depth than the tip of the caisson.

The effect of the stiffness variation with depth is presented in Figure 12 and 13 respectively for profiles $\mathrm{B}$ and $\mathrm{C}$. The outcomes are plotted with respect to the frequency normalized by the fundamental resonant frequency of the homogeneous soil layer, $\mathrm{f}_{1 \text { soil }}(4.17 \mathrm{~Hz})$. A common trend for all the stiffness components was the observed drop of stiffness at $f=0.92 f_{\text {lsoil }}$ (profile B) and $0.76 f_{\text {lsoil }}$ (profile C), which is slightly shifted back from the $1^{\text {st }}$ eigenfrequency of the homogeneous layer. The first resonance of the inhomogeneous soil profiles are in agreement with that calculated according to analytical solutions [44]. 
After the $1^{\text {st }}$ resonance the lateral stiffness coefficient is characterized by a decreasing pattern, while the slope increased for lower value of the slenderness ratio $H_{p} / d$ both for profiles $\mathrm{B}$ and $\mathrm{C}$, with profile $\mathrm{C}$ attaining larger slope increase. Regarding the coupling and rocking stiffness term, the larger slenderness ratios are related with a fairly constant variation of stiffness with frequency for profile B. On the other hand, the same stiffness terms of the caisson with shorter skirt length showed a monotonous decrease trend after the $1^{\text {st }}$ resonance for profile $\mathrm{C}$.

The imaginary part of the dynamic impedances is associated with the generated damping due to soilcaisson interaction. The damping ratio for both profiles at the lower frequency range is decreasing for increasing slenderness ratio. In addition, it was found that the horizontal impedance obtained by considering profile $\mathrm{C}$ exhibited an exponential rather than a linear trend for frequencies higher than the first resonance and particularly for $H_{p} / d=0.25$. The sensitivity of the dynamic impedances on the variation of $E_{s}$ in the high frequency range has been previously observed for end bearing piles [19].

Furthermore, looking at Figure 13 it becomes apparent that the stronger the variation of $E_{s}$ with respect to depth the higher is the reduction in dynamic stiffness after the $1^{\text {st }}$ resonance. Additionally, this trend is even more emphasized by decreasing the slenderness ratio. Therefore, it can be stated that the type of variation of soil modulus with depth has a significant effect on the dynamic response of suction caissons, especially at high frequencies.

\section{Conclusions}

In this study numerical analyses were performed to investigate the horizontal dynamic response of suction caissons embedded in viscoelastic soil. The numerical modelling procedure was validated against existing rigorous analytical solutions for end bearing and floating pile foundations. A parametric study was conducted to analyse the vibration characteristics and the effects of the main parameters on the dynamic impedances of suction caisson foundations. The numerical results provided the basis for the formulation of simple mathematical expressions for the static stiffness 
components of suction caissons. The proposed expressions accomodate a more accurate estimation of the stiffness components compared to previous analytical expressions.

The main nondimensionless parameters investigated were the slenderness ratio, the relative soil layer thickness and the relative stiffness. The skirt length was found quite substantial parameter to determine the behaviour of the suction caissons. It can be stated that the dynamic stiffness coefficients of suction caissons increased by increasing the skirt length for frequencies higher than the $1^{\text {st }}$ vertical resonance. In addition, the reduction in the dynamic stiffness due to the decrease of the soil stiffness with depth was more marked by decreasing the skirt length.

The influence of the stiffness ratio $E_{p} / E_{s}$ for homogeneous profiles was proven to affect slightly the dynamic impedances of suction caissons in the frequency range investigated. On the other hand, the type of variation of soil modulus with depth in inhomogeneous profiles had a significant effect on the dynamic response of suction caissons. The soil profile with linearly increasing stiffness with depth was shown to influence to a greater extent the dynamic stiffness and damping of the suction caisson in the examined frequency range, indicating that steep variations of stiffness with depth may lead to small dynamic stiffness and high damping ratios at high frequencies.

In addition, the study showed that the dynamic impedances of suction caissons are profoundly affected by the nondimensionless parameter $H_{s} / d$ and valuable insight on the physics of the problem is achieved by considering the relative thickness of the soil layer. The applied numerical methodology was shown to be a versatile practical tool that provides the soil-foundation dynamic impedances, which can be further applied to the dynamic response of the jacket. However, the suggested model is limited by the assumptions of linearity in the soil layer and foundation materials, and the perfect contact at the soil-foundation interface.

\section{Acknowledgement}


This work was funded by the Danish Council for Strategic Research through the project "Advancing BeYond Shallow waterS (ABYSS) - Optimal design of offshore wind turbine support structures". The author would also like to acknowledge funding from the Technical University of Denmark for this study.

\section{References}

[1] de Vries WE. Assessment of bottom-mounted support structure type with conventional design stiffness and installation techniques for typical deep water sites. Deliverable report, 2007.

[2] Houlsby GT, Ibsen LB, Byrne BW. Suction caissons for wind turbines. Front Offshore Geotech ISFOG 2005 - Perth, Australia, 2005:75-94.

[3] Byrne BW, Houlsby GT. Assessing novel foundation options for offshore wind turbines. World Mar Tech Conf, London, UK, 2006.

[4] DNV-OS-J101, Design of Offshore Wind Turbines, Det Norskes Veritas, Norway, 2004.

[5] Devriendt C, Jordaens PJ, De Sitter G, Guillaume P. Estimating damping of an offshore wind turbine using an overspeed stop and ambient excitation. 15th Int Conf on Exp Mech (ICEM15), Porto, Portugal, 2897, 2012.

[6] Wolf JP. Dynamic soil-structure interaction. Prentice Hall int.; 1985.

[7] Adhikari S, Bhattacharya, S. Dynamic analysis of wind turbine towers on flexible foundations. Shock Vib 2012;19. doi:10.3233/SAV-2012-0615.

[8] Alexander NA, Bhattacharya, S. The dynamics of monopile supported wind turbines in nonlinear soil. Proc 8th Int Conf Struct Dyn, Leuven, Belgium, 2011.

[9] Zania V. Natural vibration frequency and damping of slender structures founded on monopiles. Soil Dyn Earthq Eng 2014;59:8-20. doi:10.1016/j.soildyn.2014.01.007.

[10] Novak M, Nogami T. Soil-pile interaction in horizontal vibration. Earthq Eng Struct Dyn 1977;5:263-81. doi:10.1002/eqe.4290050305.

[11] Nogami T, Novak M. Resistance of soil to a horizontally vibrating pile. Earthq Eng Struct Dyn 1977;5:249-61. doi:10.1002/eqe.4290050304.

[12] Nogami T. Coefficients of soil reaction to pile vibration. J Geotech Eng Div 1980;106.

[13] Novak M. Dynamic Stiffness and Damping of Piles. Can Geotech J 1974;11(4):574-98. doi:10.1139/t74-059.

[14] Novak M, Aboul- Ella F. Impedance functions of piles in layered media. J Eng Mech Div 1978; 104(3):643-661.

[15] Mylonakis G. Elastodynamic model for large-diameter end-bearing shafts. Soils Found 2001;41(3):31-44.

[16] Blaney GW, Kausel E, Roesset J. Dynamic stiffness of piles. Proc 2nd Int Conf Num Meth in Geomech, Blacksburg, USA, 2, 1001-1012, 1976.

[17] Roesset JM, Angelides D. Dynamic stiffness of piles. Proc Int Conf Num Meth Offshore Piling, Institution of Civil Engineers, London, 1980. 
[18] Velez A, Gazetas G, Krishnan R. Lateral dynamic response of constrained head piles. J Geotech Eng 1983;109:106381. doi:10.1061/(ASCE)0733-9410(1983)109:8(1063).

[19] Gazetas G. Seismic response of end-bearing single piles. Int J Soil Dyn Earthq Eng 1984;3(2):82-93. doi:10.1016/0261-7277(84)90003-2.

[20] Gazetas G, Dobry R. Horizontal response of piles in layered soils. J Geotech Eng 1984;110(1):20-40. doi:10.1061/(ASCE)0733-9410(1984)110:1(20).

[21] Nozoe H, Gyōten Y, Fukusumi T. Dynamic analysis of a soil-pile system by the finite Fourier-Henkel transformation method - Case of a floating pile in horizontal vibration. Theoretical and applied mechanics 1985; 33: 377-392.

[22] Latini C, Zania V, Johannesson B. Dynamic stiffness and damping of foundations for jacket structures. Proc 6th Int Conf Earthq Geotech Eng, 2015.

[23] Haldar SS, Bose SK. Dynamic soil stiffness in lateral vibrations of a floating pile. Soil Dyn Earthq Eng 1990; 9(1): $51-56$.

[24] El-Marsafawi H, Kaynia AM, Novak M. Interaction factors and the superposition method for pile group dynamic analysis, Report GEOT192, Geotechnical Research Center, The University of Western Ontario; 1992.

[25] Syngros C. Seismic Response of piles and pile-supported bridge piers evaluated through case histories [Ph.D. thesis], City University of New York; 2004.

[26] Kaynia AM, Kausel E. Dynamic stiffness and seismic response of pile groups. Research Report R82-03, Cambridge, MA: Massachusetts Institute of Technology; 1982.

[27] Maeso O, Aznárez JJ, García F. Dynamic impedances of piles and groups of piles in saturated soils. Comput Struct 2005; 83(10): 769-782.

[28] Padrón LA, Aznárez JJ, Maeso O. Dynamic analysis of piled foundations in stratified soils by a BEM-FEM model. Soil Dyn Earthq Eng 2008;28(5):333-46.

[29] Jin B, Zhou D, Zhong Z. Lateral dynamic compliance of pile embedded in poroelastic half space. Int J Soil Dyn Earthq Eng 2001; 21(6): 519-525.

[30] Pak RYS, Jennings PC. Elastodynamic response of piles under transverse excitations. J Eng Mech 1987;113(7):110116.

[31] Rajapakse RKND, Shah AH. On the lateral harmonic motion of an elastic bar embedded in an elastic half-space. Int J Solids Struct 1987;23(2):287-303.

[32] Larsen KA, Ibsen LB, Barari A. Modified expression for the failure criterion of bucket foundations subjected to combined loading. Can Geotech J 2013; 50(12): 1250-1259.

[33] Randolph MF, House AR. Analysis of suction caisson capacity in clay. Proc Annu Offshore Technol Conf, 2002.

[34] Aubeny C, Murff JD. Simplified limit solutions for undrained capacity of suction anchors. Deepwater Mooring Systems: Concepts, Design, Analysis and Materials, Texas, USA, 76-90, 2003.

[35] Kourkoulis RS, Lekkakis PC, Gelagoti FM, Kaynia AM. Suction caisson foundations for offshore wind turbines subjected to wave and earthquake loading: effect of soil-foundation interface. Géotechnique 2014;64(3):171-85. doi:10.1680/geot.12.P.179.

[36] Liingaard M. Dynamic behavior of suction caissons [PhD Thesis]. Aalborg University, Denmark, 2006.

[37] Latini C, Cisternino, M, Zania V. Dynamic stiffness of horizontally vibrating suction caissons. Proc 17th Nord Geotech Meet, 2016. 
[38] Bhattacharya S, Nikitas N, Garnsey J, Alexander NA, Cox J, Lombardi D, Nash DF. Observed dynamic soil-structure interaction in scale testing of offshore wind turbine foundations. Soil Dyn Earthq Eng 2013;54:47-60.

[39] Simulia DS. Abaqus 6.13 User's Manual. Dassault Systems, Providence, RI. 2003.

[40] Darendeli MB. Development of a new family of normalized modulus reduction and material damping curves [PhD Thesis]. The University of Texas at Austin, USA, 2001.

[41] Poulos HG, Davis EH. Pile foundation analysis and design. New York, NY: John Wiley \& Sons; 1980.

[42] Randolph MF. The response of flexible piles to lateral loading. Géotechnique 1981;31(2):247-59. doi:10.1680/geot.1981.31.2.247.

[43] Gazetas G. Analysis of machine foundation vibrations: State of the art. Int J Soil Dyn Earthq Eng 1983;2(1):2-42. doi:10.1016/0261-7277(83)90025-6.

[44] Rovithis EN, Parashakis H, Mylonakis GE. 1D harmonic response of layered inhomogeneous soil: Analytical investigation. Soil Dyn Earthq Eng 2011;31(7):879-90. doi:10.1016/j.soildyn.2011.01.007.

[45] Carter JP, Kulhawy FH. Analysis of laterally loaded shafts in rock. J Geotech Eng 1992;118(6):839-55. doi:10.1061/(ASCE)0733-9410(1992)118:6(839).

[46] Wolf JP, Deeks AJ. Cones to model foundation vibrations: incompressible soil and axi-symmetric embedment of arbitrary shape. Soil Dyn Earthq Eng 2004;24(12):963-78. doi:10.1016/j.soildyn.2004.06.016.

[47] Gelagoti FM, Lekkakis PP, Kourkoulis RS, Gazetas G. Estimation of elastic and non-linear stiffness coefficients for suction caisson foundations. Proc Xvi European Conf Soil Mech Geotech Eng, Edinburgh, UK, 2015.

[48] Shadlou M, Bhattacharya S. Dynamic stiffness of monopiles supporting offshore wind turbine generators. Soil Dyn Earthq Eng 2016; 88,15-32. 
$\mathrm{V}_{\mathrm{H}}$ : reference base soil shear wave velocity

\section{NOTATION}

\section{Latin upper case}

$\mathrm{E}_{\mathrm{s}}$ : soil modulus of elasticity

$\mathrm{E}_{\mathrm{p}}$ : Young modulus of foundation

\section{Latin lower case}

G: soil shear modulus

$\mathrm{H}_{\mathrm{s}}$ : thickness of soil layer

$\mathrm{H}_{\mathrm{p}}$ : height of foundation

$\mathrm{d}$ : diameter of foundation

$\mathrm{n}$ : dimensionless inhomogeneity factor

$\mathrm{r}_{0}$ : radius of foundation

I : moment of inertia of pile

t: thickness of foundation

$\mathrm{L}_{\text {inf: }}$ length of the infinite soil domain

$\mathrm{L}_{\text {fin }}$ : length of the finite soil domain

$\mathrm{K}_{\mathrm{r}}$ : foundation flexibility factor

$K_{s u}$ : dynamic stiffness coefficient -real part- force for unit displacement

$K_{m u}$ : dynamic stiffness coefficient -real partmoment for unit displacement

$K_{s \vartheta}:$ dynamic stiffness coefficient -real part- force per unit rotation

$K_{m \vartheta}$ : dynamic stiffness coefficient -real partmoment for unit rotation

$K^{0}{ }_{s u}$ : static stiffness coefficient - force for unit displacement

$K^{0}{ }_{m u}$ : static stiffness coefficient - moment for unit displacement

$K^{0}{ }_{s \vartheta}$ : static stiffness coefficient - force for unit rotation

$K^{0}{ }_{m \vartheta}$ : static stiffness coefficient - moment for unit rotation

$M$ : reaction moment at the foundation head

$S$ : horizontal reaction force at the foundation head

$\mathrm{V}_{\mathrm{s}}$ : soil shear wave velocity

$\mathrm{V}_{0}$ : surface soil shear wave velocity

$\mathrm{t}_{\text {skirt }}$ thickness of caisson skirt

$u$ : translational degree of freedom at the foundation head

\section{Greek}

$\alpha_{0}$ : dimensionless eigenfrequency of soil layer $\zeta_{s u}$ : damping coefficient - force for unit displacement

$\zeta_{m u}$ : damping coefficient - moment for unit displacement

$\zeta_{s \vartheta}$ : damping coefficient - force for unit rotation

$\zeta_{m \vartheta}$ : damping coefficient - moment for unit rotation

$\vartheta$ : rotational degree of freedom at the foundation head

v: soil's Poisson's ratio

$\xi$ : hysteretic soil damping ratio

$\rho$ : density of soil

$\eta$ : wave velocity ratio 


\section{TABLES}

Table 1. Static end bearing and floating pile stiffness obtained from the numerical models and the analytical solutions $[10,22]$.

\begin{tabular}{|c|c|c|c|c|}
\hline & Reference & $\mathbf{K}_{\mathrm{Su}}^{0} / \mathbf{E}_{\mathrm{s}} \mathbf{d}$ & $\mathbf{K}_{\mathrm{S} \theta}^{0} / \mathbf{E}_{\mathrm{s}} \mathbf{d}^{2}$ & $\mathbf{K}_{\mathrm{M} \theta}^{0} / \mathbf{E}_{\mathrm{s}} \mathbf{d}^{3}$ \\
\hline \multirow[t]{2}{*}{ Figure 2A } & Novak and Nogami [10] & 2.24 & -1.02 & 1.23 \\
\hline & Numerical model & 1.96 & -0.71 & 1.26 \\
\hline \multirow[t]{2}{*}{ Figure 2B } & Latini et al. [22] & 1.96 & -0.93 & 1.17 \\
\hline & Numerical model & 1.91 & -0.70 & 1.30 \\
\hline
\end{tabular}


Table 2. Dimensionless parameters and cases selected in the parametric analysis.

\begin{tabular}{|c|c|c|c|c|c|c|c|c|c|c|c|c|}
\hline \multirow[b]{2}{*}{ Case Nr. } & \multirow[b]{2}{*}{$\begin{array}{c}\mathbf{H}_{\mathbf{s}} \\
{[\mathbf{m}]}\end{array}$} & \multirow[b]{2}{*}{$\begin{array}{c}\mathbf{H}_{\mathrm{p}} \\
{[\mathrm{m}]}\end{array}$} & \multirow[b]{2}{*}{$\begin{array}{c}\mathbf{d} \\
{[\mathbf{m}]}\end{array}$} & \multirow[b]{2}{*}{$\mathbf{H}_{\mathrm{p}} / \mathbf{d}$} & \multirow[b]{2}{*}{$\mathbf{H}_{\mathbf{s}} / \mathbf{d}$} & \multicolumn{4}{|c|}{ Soil Profile } & \multirow[b]{2}{*}{$\mathbf{E}_{\mathbf{p}} / \mathbf{E}_{\mathbf{s}}$} & \multirow[b]{2}{*}{$\mathbf{K}_{\mathbf{r}}$} & \multirow[b]{2}{*}{ Behaviour } \\
\hline & & & & & & Type & $\mathbf{n}$ & $\underset{[\mathrm{m} / \mathrm{s}]}{\mathbf{V}_{\mathbf{H}}}$ & $\mathbf{V}_{\mathbf{0}} / \mathbf{V}_{\mathbf{H}}$ & & & \\
\hline $\begin{array}{c}1 \\
\text { (Ref.) }\end{array}$ & 30 & 10 & 1 & 10 & 10 & A & 1 & 250 & 1 & 60 & $2.88 \mathrm{e}-4$ & Flexible \\
\hline 2 & 30 & 10 & 5 & 2 & 6 & A & 1 & 250 & 1 & 60 & $1.80 \mathrm{e}-1$ & Rigid \\
\hline 3 & 30 & 7.5 & 5 & 1.5 & 6 & A & 1 & 250 & 1 & 60 & $5.68 \mathrm{e}-1$ & Rigid \\
\hline 4 & 30 & 5 & 5 & 1 & 6 & A & 1 & 250 & 1 & 60 & 2.88 & Rigid \\
\hline 5 & 30 & 2.5 & 5 & 0.5 & 6 & $\mathrm{~A}$ & 1 & 250 & 1 & 60 & 46.08 & Rigid \\
\hline 6 & 30 & 1.25 & 5 & 0.25 & 6 & A & 1 & 250 & 1 & 60 & 737.3 & Rigid \\
\hline 7 & 30 & 1 & 4 & 0.25 & 7.5 & A & 1 & 250 & 1 & 60 & 737.3 & Rigid \\
\hline 8 & 15 & 0.5 & 2 & 0.25 & 7.5 & A & 1 & 250 & 1 & 60 & 737.3 & Rigid \\
\hline 9 & 30 & 8 & 4 & 2 & 7.5 & A & 1 & 250 & 1 & 60 & $1.80 \mathrm{e}-1$ & Rigid \\
\hline 10 & 15 & 4 & 2 & 2 & 7.5 & A & 1 & 250 & 1 & 60 & $1.80 \mathrm{e}-1$ & Rigid \\
\hline 11 & 30 & 0.5 & 2 & 0.25 & 15 & $\mathrm{~A}$ & 1 & 250 & 1 & 60 & 737.3 & Rigid \\
\hline 12 & 30 & 4 & 2 & 2 & 15 & A & 1 & 250 & 1 & 60 & $1.80 \mathrm{e}-1$ & Rigid \\
\hline 13 & 30 & 10 & 5 & 2 & 6 & A & 1 & 300 & 1 & 41 & $1.28 \mathrm{e}-1$ & Rigid \\
\hline 14 & 30 & 10 & 5 & 2 & 6 & A & 1 & 400 & 1 & 23 & $7.20 \mathrm{e}-2$ & Rigid \\
\hline 15 & 30 & 10 & 5 & 2 & 6 & A & 1 & 500 & 1 & 15 & $4.71 \mathrm{e}-2$ & Rigid \\
\hline 16 & 30 & 1.25 & 5 & 0.25 & 6 & A & 1 & 300 & 1 & 41 & 515.6 & Rigid \\
\hline 17 & 30 & 1.25 & 5 & 0.25 & 6 & A & 1 & 400 & 1 & 23 & 295.1 & Rigid \\
\hline 18 & 30 & 1.25 & 5 & 0.25 & 6 & A & 1 & 500 & 1 & 15 & 193.0 & Rigid \\
\hline 19 & 30 & 7.5 & 5 & 1.5 & 6 & A & 1 & 500 & 1 & 15 & $1.49 \mathrm{e}-1$ & Rigid \\
\hline 20 & 30 & 5 & 5 & 1 & 6 & A & 1 & 500 & 1 & 15 & $7.54 \mathrm{e}-1$ & Rigid \\
\hline 21 & 30 & 2.5 & 5 & 0.5 & 6 & A & 1 & 500 & 1 & 15 & 12.1 & Rigid \\
\hline 22 & 30 & 10 & 5 & 2 & 6 & B & 0.25 & 500 & 0.01 & 15 & $4.71 \mathrm{e}-2$ & Rigid \\
\hline 23 & 30 & 5 & 5 & 1 & 6 & B & 0.25 & 500 & 0.01 & 15 & $7.54 \mathrm{e}-1$ & Rigid \\
\hline 24 & 30 & 1.25 & 5 & 0.25 & 6 & B & 0.25 & 500 & 0.01 & 15 & 193.0 & Rigid \\
\hline 25 & 30 & 10 & 5 & 2 & 6 & $\mathrm{C}$ & 0.5 & 500 & 0.1 & 15 & $4.71 \mathrm{e}-2$ & Rigid \\
\hline 26 & 30 & 5 & 5 & 1 & 6 & $\mathrm{C}$ & 0.5 & 500 & 0.1 & 15 & $7.54 \mathrm{e}-1$ & Rigid \\
\hline 27 & 30 & 1.25 & 5 & 0.25 & 6 & $\mathrm{C}$ & 0.5 & 500 & 0.1 & 15 & 193.0 & Rigid \\
\hline
\end{tabular}




\section{FIGURE LEGENDS}

Figure 1: Finite element model of the foundation and the surrounding soil.

Figure 2: Illustration of the two soil profiles and the foundation types investigated in this study. The soil profile and the foundation type in Figure $2 \mathrm{~A}$ and $2 \mathrm{~B}$ are adopted in the validation; while those in Figure $2 \mathrm{C}$ are deployed in the parametric study.

Figure 3: End bearing pile. Variation of the translational stiffness and damping coefficients with respect to the dimensionless frequency (a) and distribution of the pile displacement along the depth at the three first eigenfrequencies of the soil layer (b) for profile in Figure 2a.

Figure 4: Variation of the three dynamic stiffness coefficients with respect to the dimensionless frequency. The real component and the imaginary component for profile in Figure $2 b$.

Figure 5: Distribution of the pile displacement along the depth at the three first eigenfrequencies of the soil layer for profile in Figure $2 b$.

Figure 6: Soil profiles considered for dynamic response of suction caissons.

Figure 7: Static stiffness components of suction caissons. Mathematical expressions for the static stiffness components (a). Comparison of the static stiffness components given by the numerical model and three analytical expressions(b).

Figure 8: Variation of the three dynamic stiffness and damping coefficients with respect to the nondimensional frequency. Effect of the slenderness ratio on the real component (a) and the imaginary component (b).

Figure 9: Variation of the three dynamic stiffness and damping coefficients with respect to the nondimensional frequency. Effect of the diameter of suction caisson on the real component (a) and the imaginary component (b).

Figure 10: Variation of the three dynamic stiffness and damping coefficients with respect to the nondimensional frequency. Effect of the relative thickness of the soil layer on the real component (a) and the imaginary component (b).

Figure 11: Variation of the three dynamic stiffness and damping coefficients with respect to the nondimensional frequency. Effect of the stiffness of homogeneous soil layer (profile A) on the real component and the imaginary component for $\mathrm{H}_{\mathrm{p}} / \mathrm{d}=2$.

Figure 12: Variation of the three dynamic stiffness and damping coefficients with respect to the nondimensional frequency. Effect of slenderness ratio in the inhomogeneous soil layer (profile B) on the real component (a) and the imaginary component (b).

Figure 13: Variation of the three dynamic stiffness and damping coefficients with respect to the nondimensional frequency. Effect of the slenderness ratio in the inhomogeneous soil layer (profile $\mathrm{C}$ ) on the real component (a) and the imaginary component (b). 


\section{FIGURES}

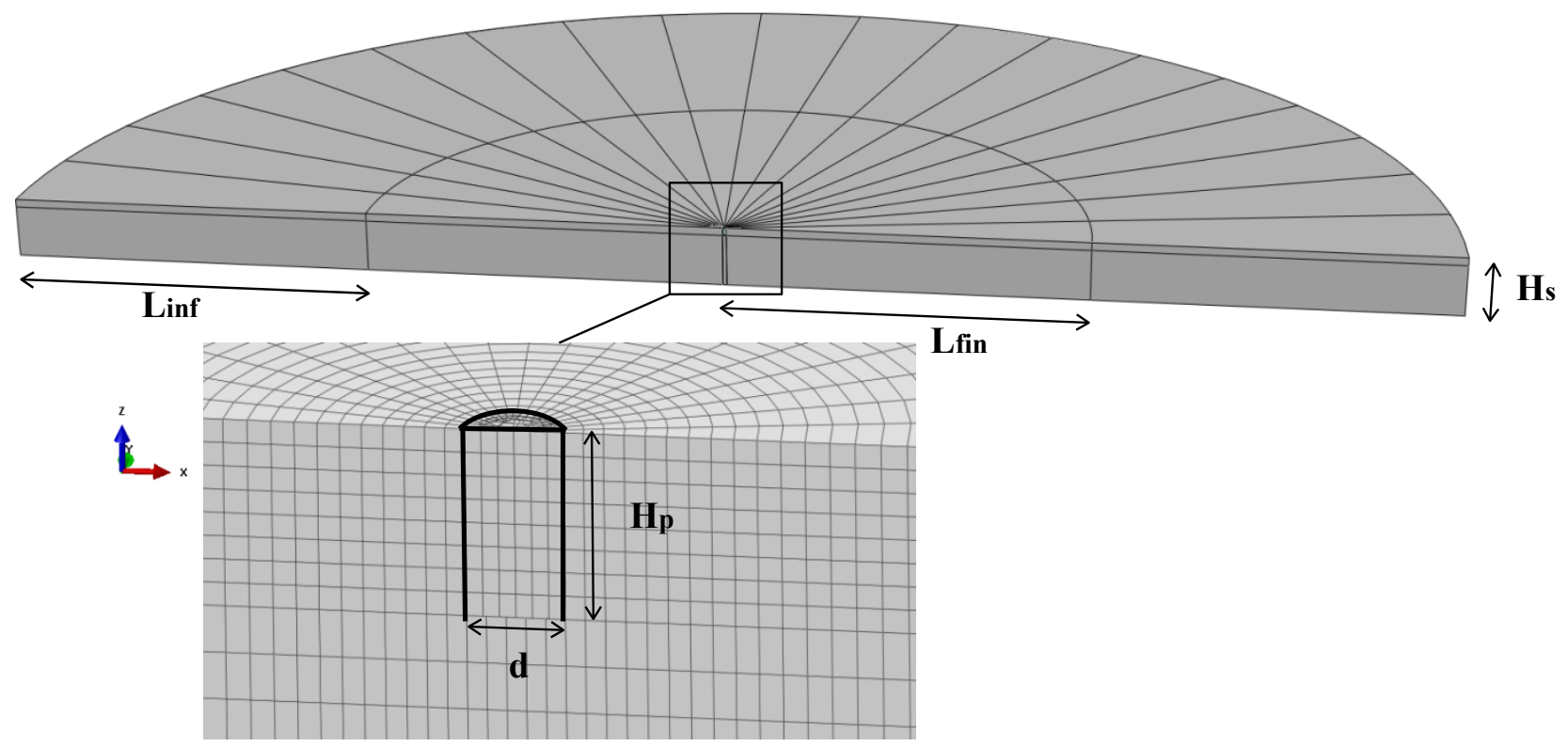

Figure 1: Finite element model of the foundation and the surrounding soil. 
A

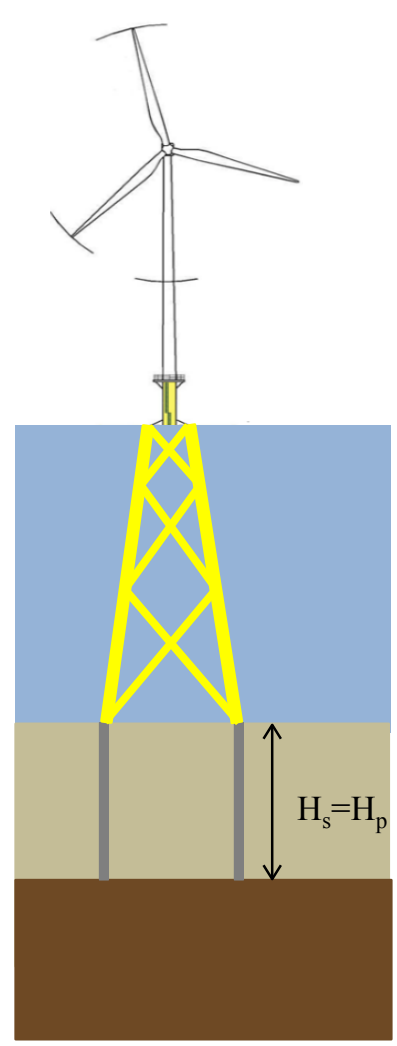

B

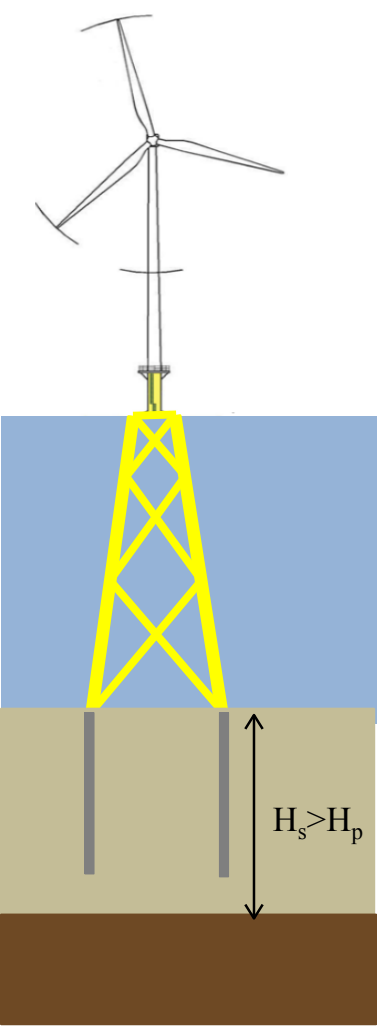

$\mathbf{C}$

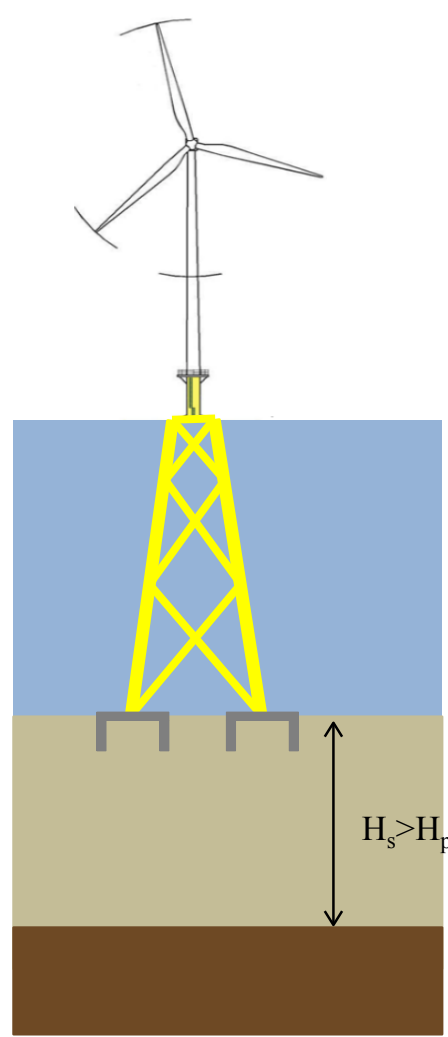

Figure 2: Illustration of the two soil profiles and the foundation types investigated in this study. The soil profile and the foundation type in Figure $2 \mathrm{~A}$ and $2 \mathrm{~B}$ are adopted in the validation; while those in Figure $2 \mathrm{C}$ are deployed in the parametric study. 

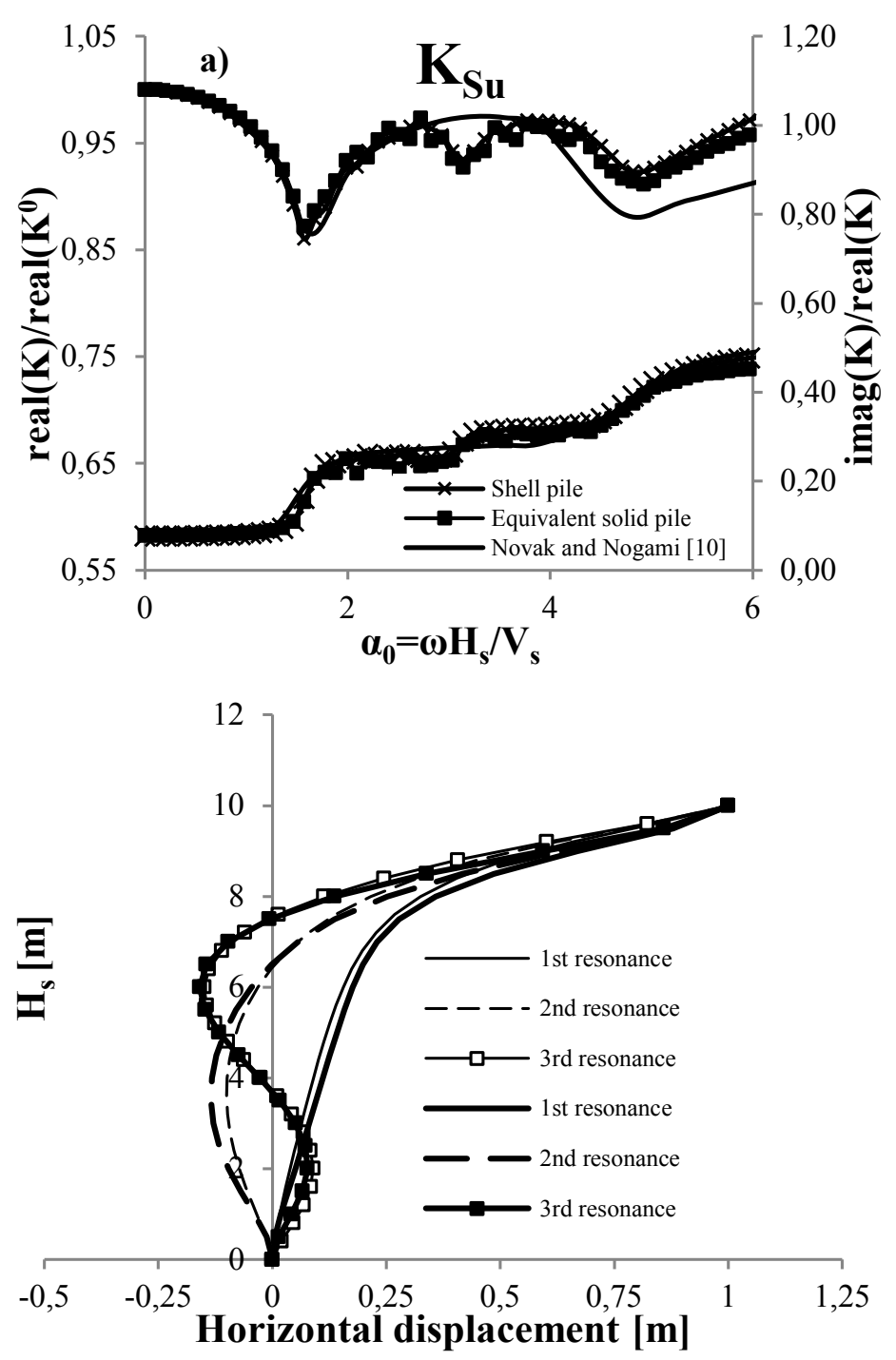

Figure 3: End bearing pile. Variation of the translational stiffness and damping coefficients with respect to the dimensionless frequency (a) and distribution of the pile displacement along the depth at the three first eigenfrequencies of the soil layer (b) for profile in Figure 2a. 

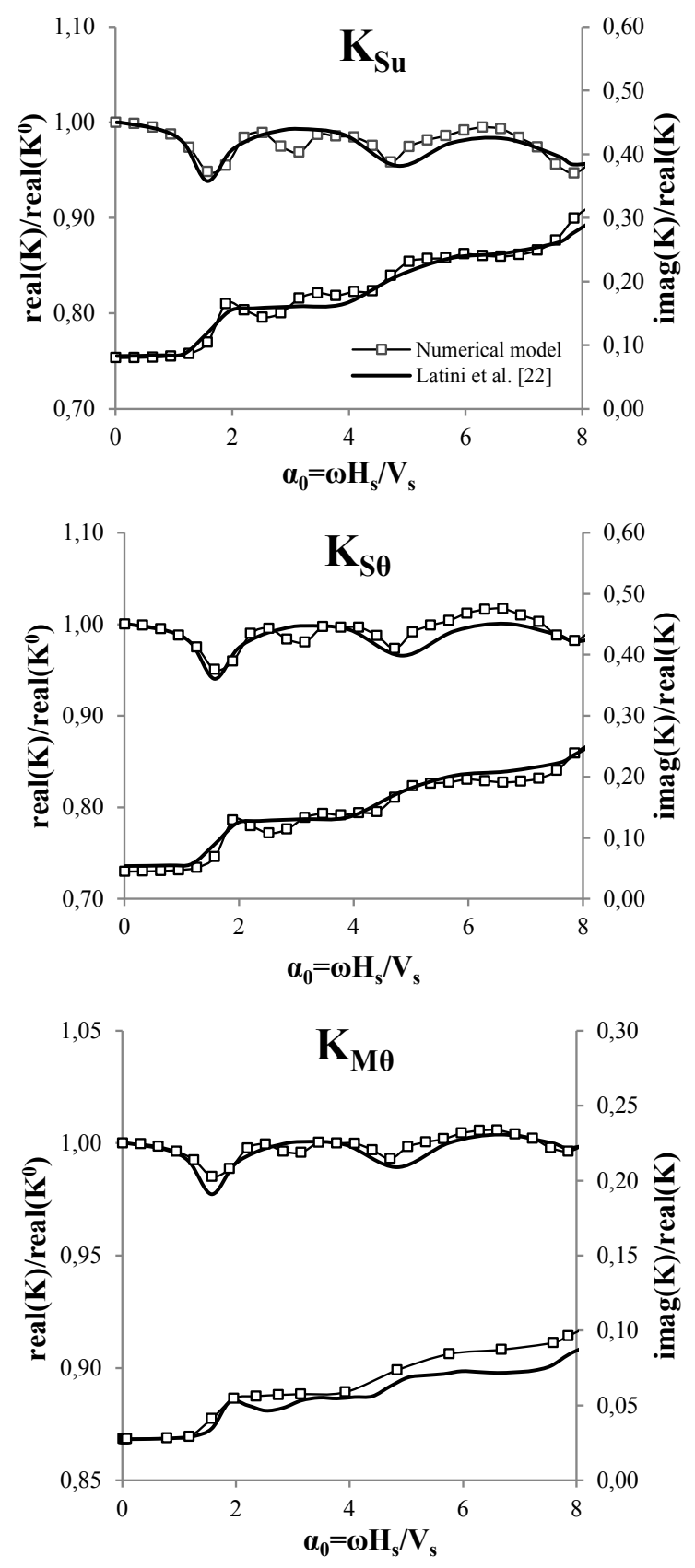

Figure 4: Variation of the three dynamic stiffness coefficients with respect to the dimensionless frequency. The real component and the imaginary component for profile in Figure $2 \mathrm{~b}$. 


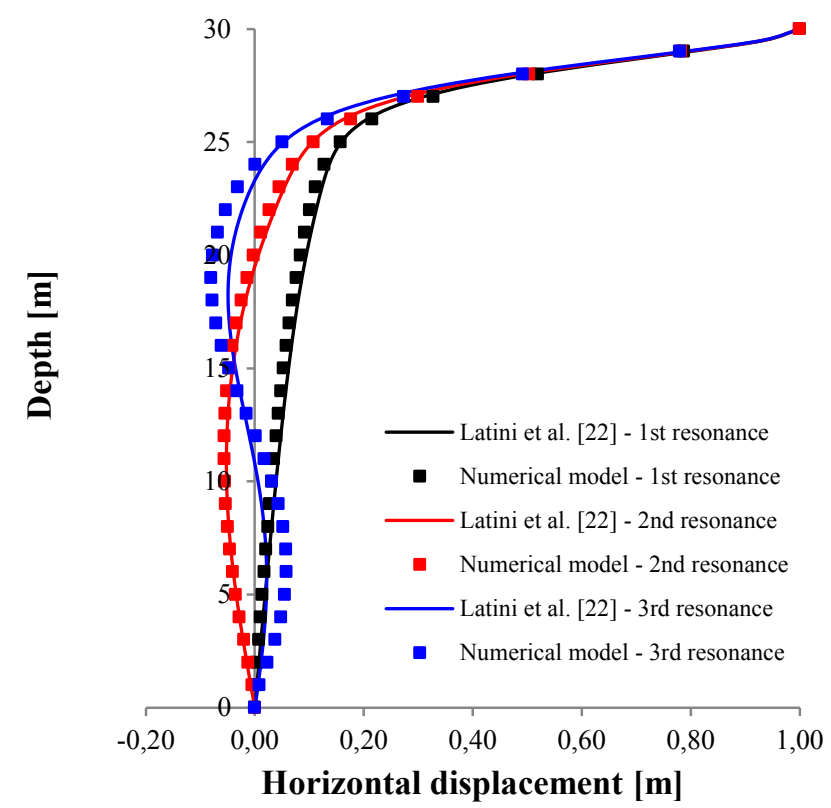

Figure 5: Distribution of the pile displacement along the depth at the three first eigenfrequencies of the soil layer for Profile 2. 


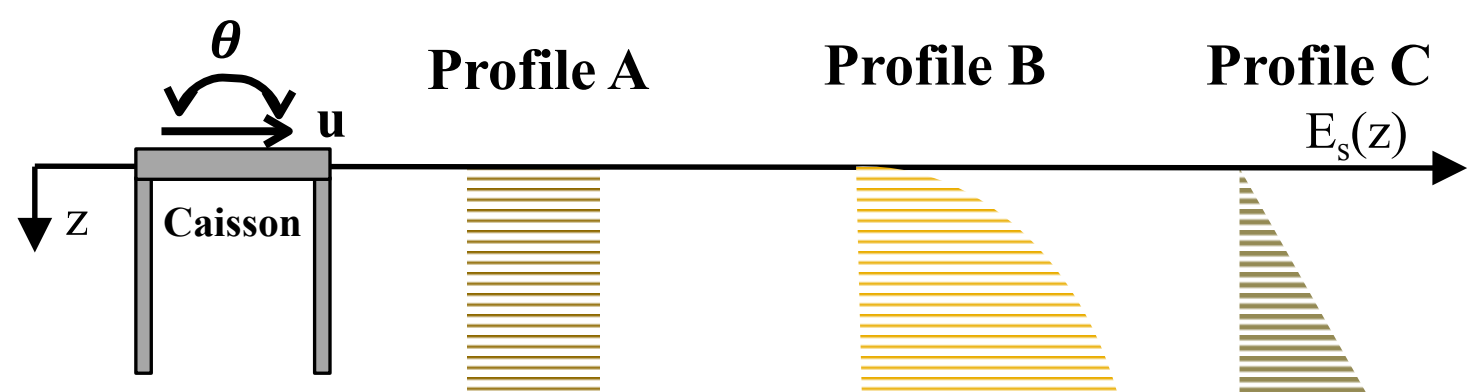

Figure 6: Soil profiles considered for dynamic response of suction caissons. 

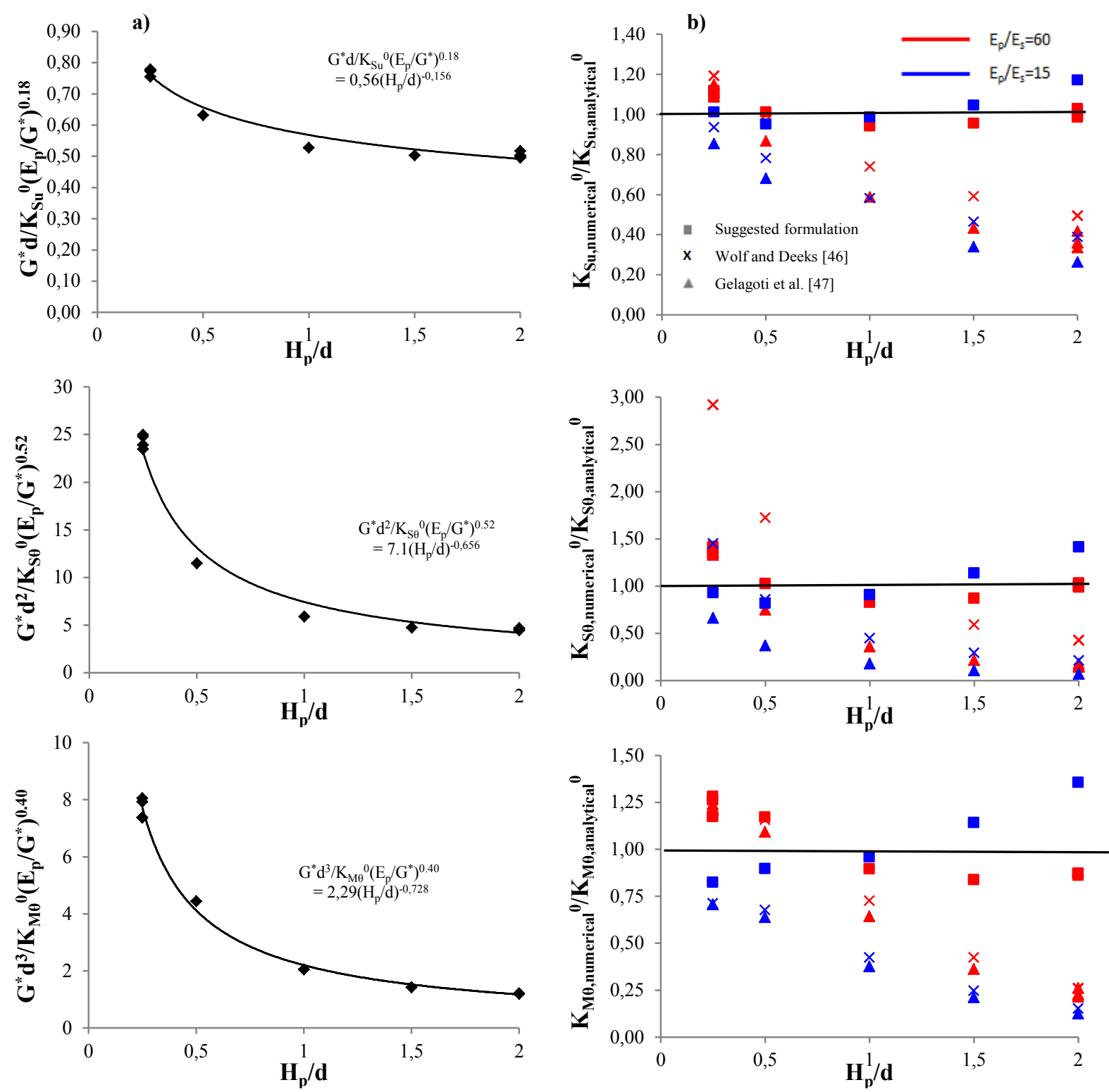

Figure 7: Static stiffness components of suction caissons. Mathematical expressions for the static stiffness components (a). Comparison of the static stiffness components given by the numerical model and three analytical expressions (b). 

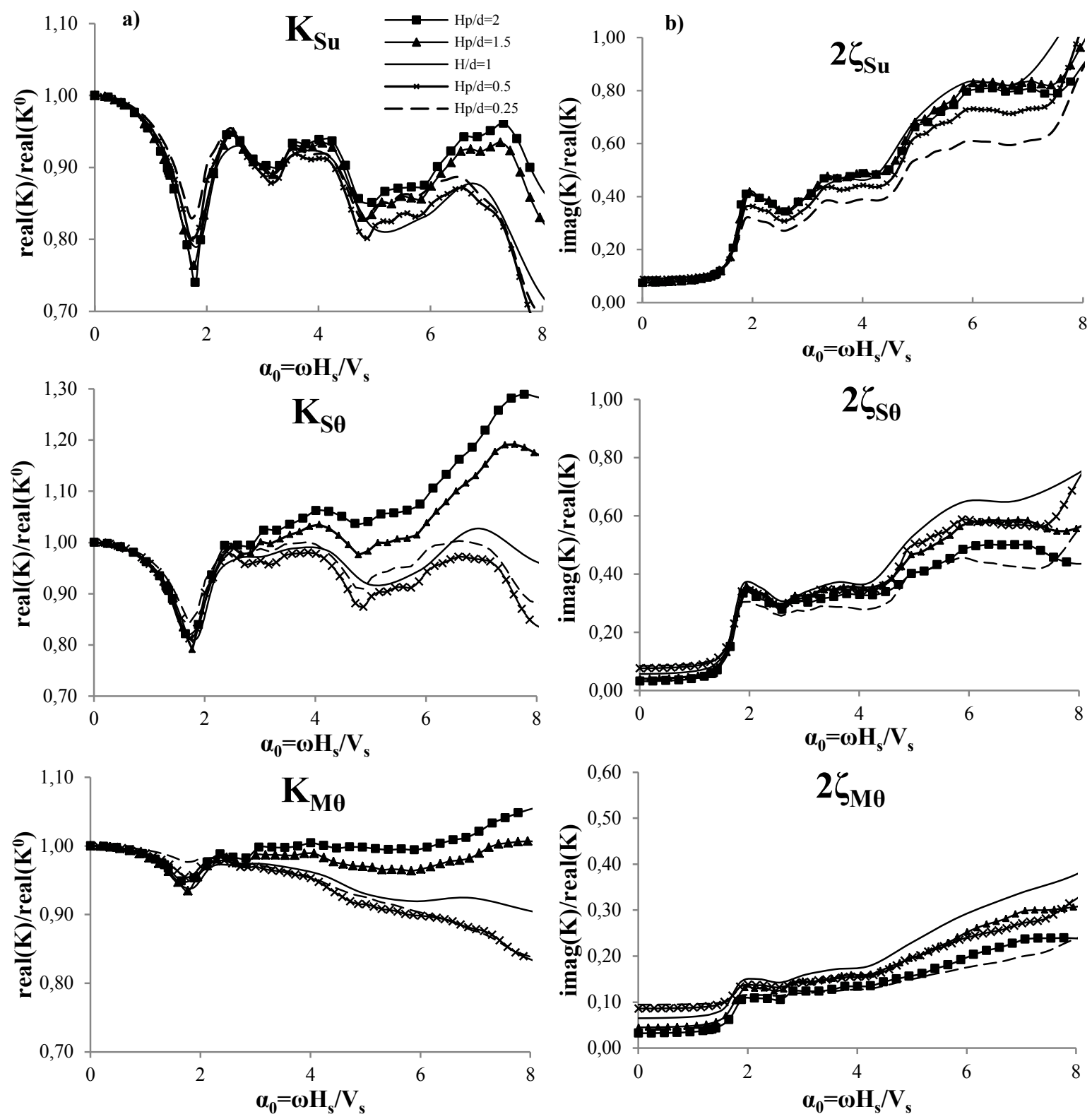

Figure 8: Variation of the three dynamic stiffness and damping coefficients with respect to the nondimensional frequency. Effect of the slenderness ratio on the real component (a) and the imaginary component (b). 



Figure 9: Variation of the three dynamic stiffness and damping coefficients with respect to the nondimensional frequency. Effect of the diameter of suction caisson on the real component (a) and the imaginary component (b). 

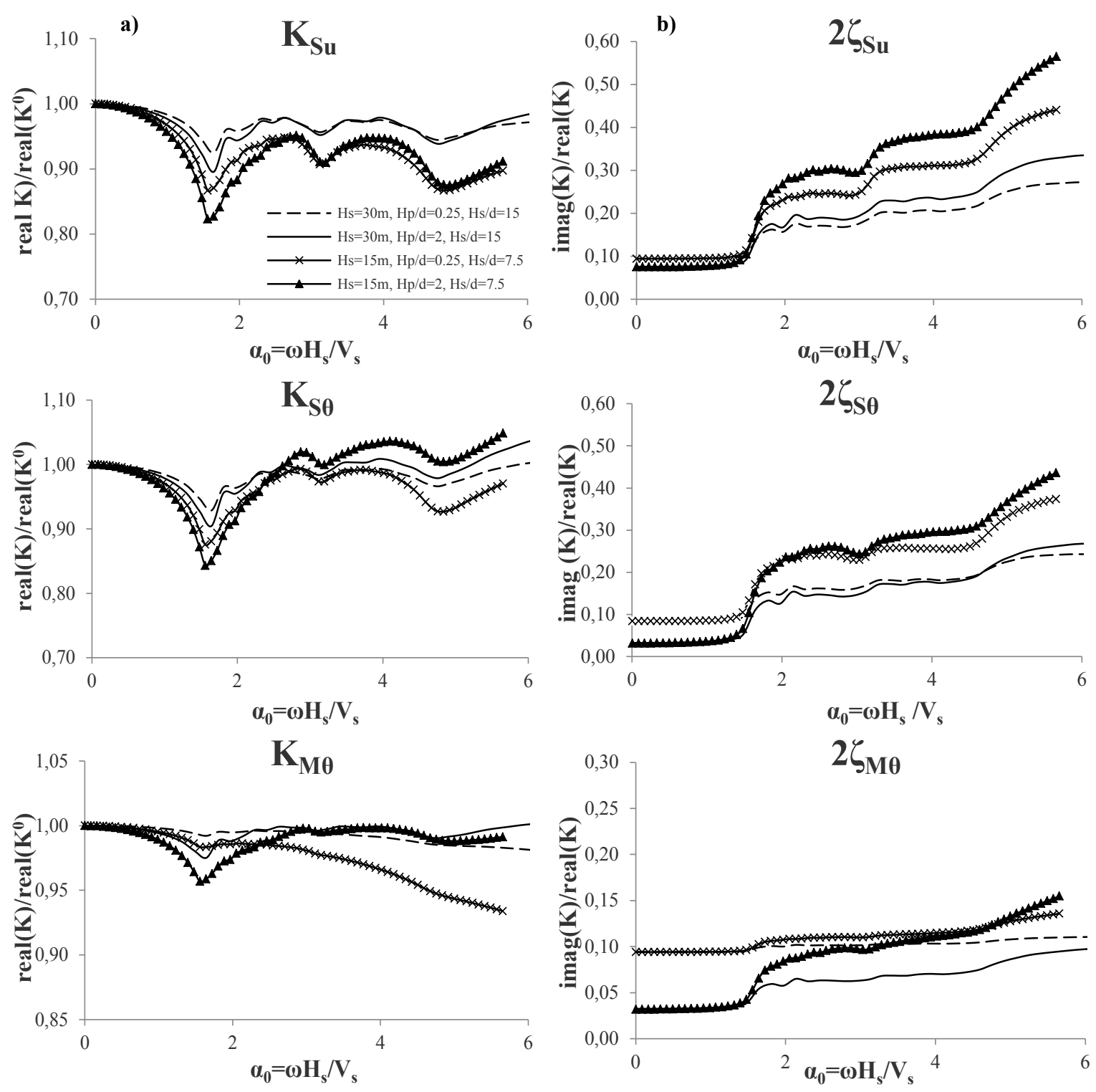

Figure 10: Variation of the three dynamic stiffness and damping coefficients with respect to the nondimensional frequency. Effect of the relative thickness of the soil layer on the real component (a) and the imaginary component (b). 

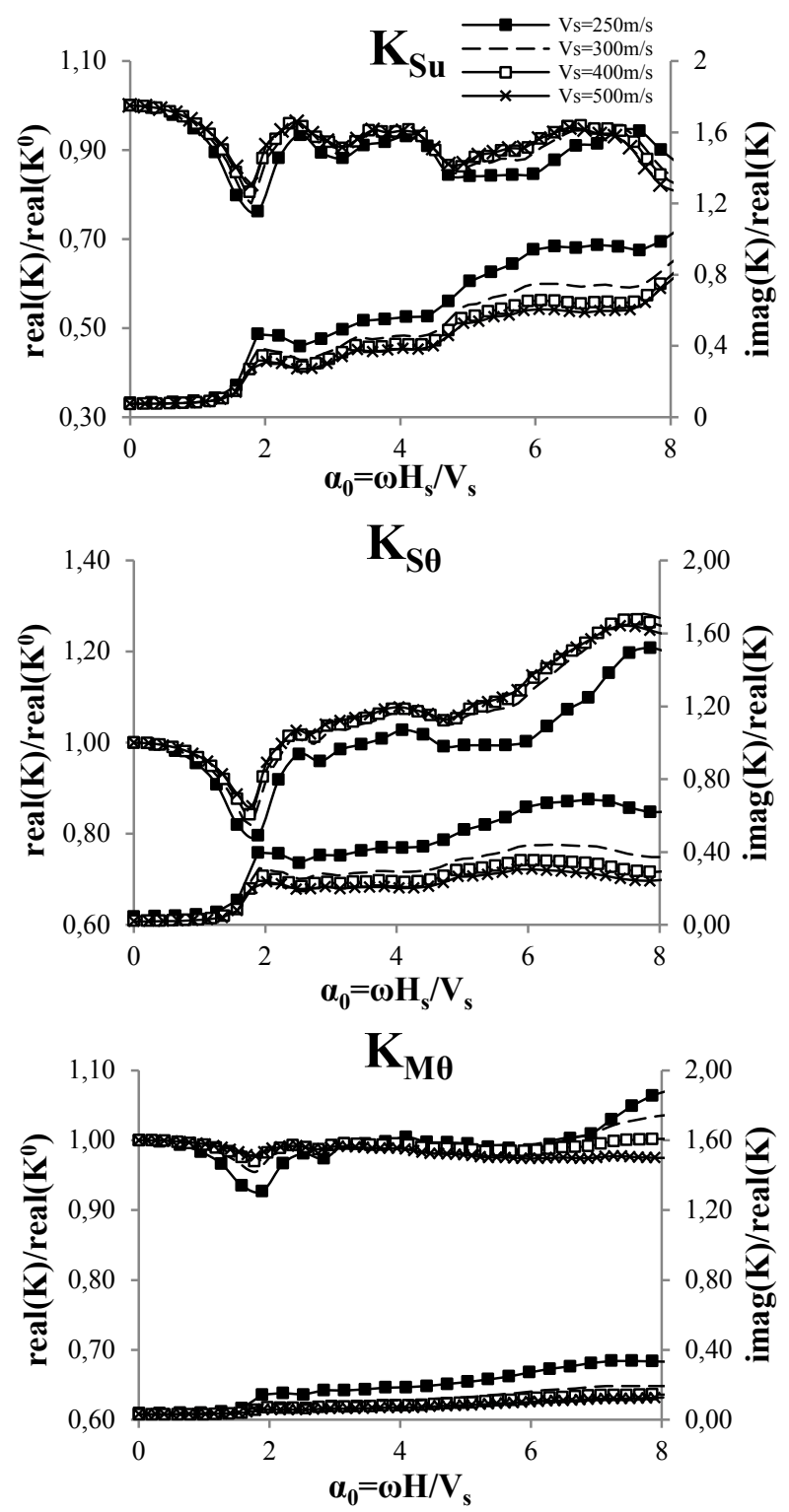

Figure 11: Variation of the three dynamic stiffness and damping coefficients with respect to the nondimensional frequency. Effect of the stiffness of homogeneous soil layer (profile A) on the real component and the imaginary component for $\mathrm{H}_{\mathrm{p}} / \mathrm{d}=2$. 

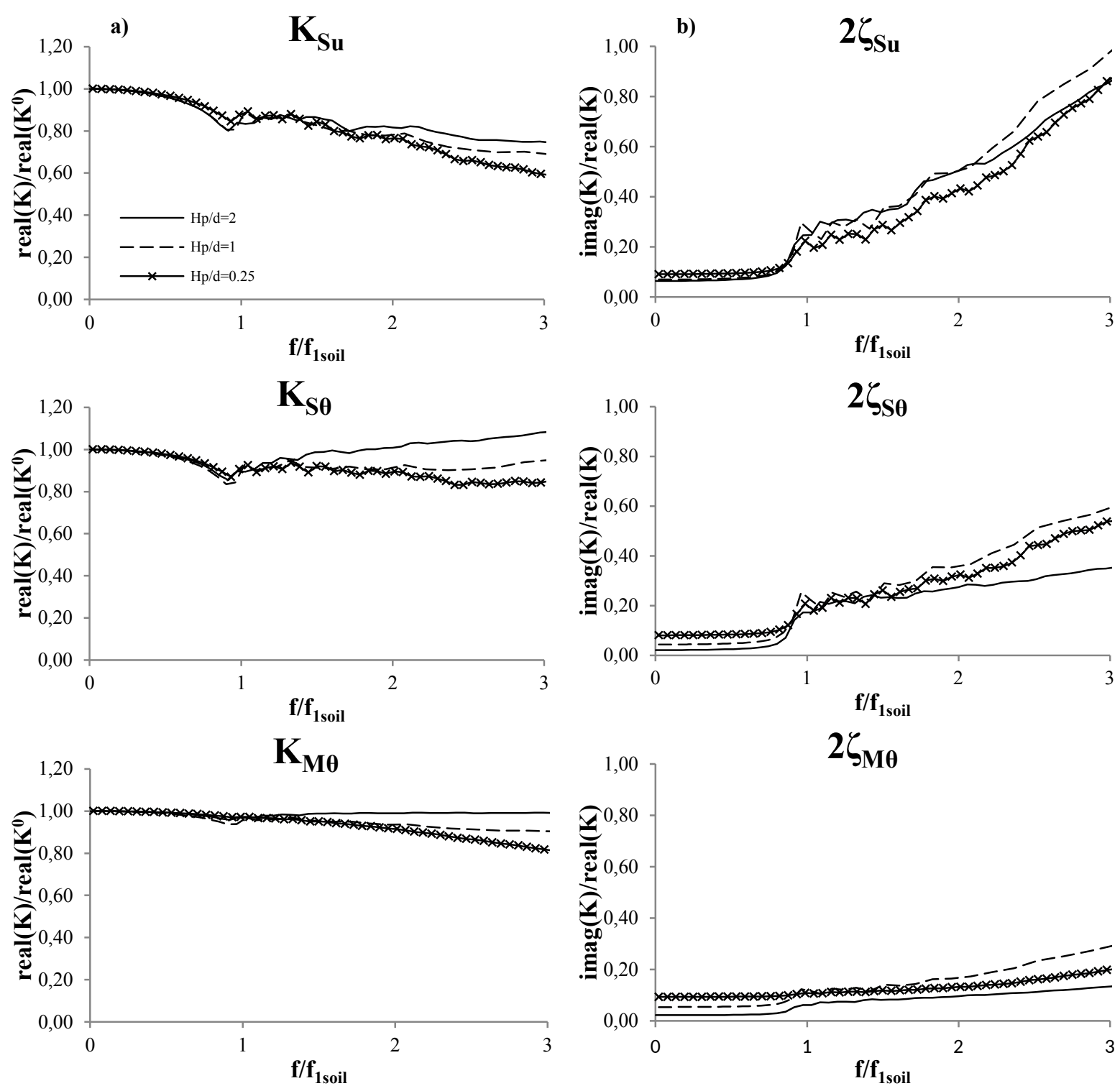

Figure 12: Variation of the three dynamic stiffness and damping coefficients with respect to the nondimensional frequency. Effect of slenderness ratio in the inhomogeneous soil layer (profile B) on the real component (a) and the imaginary component (b). 

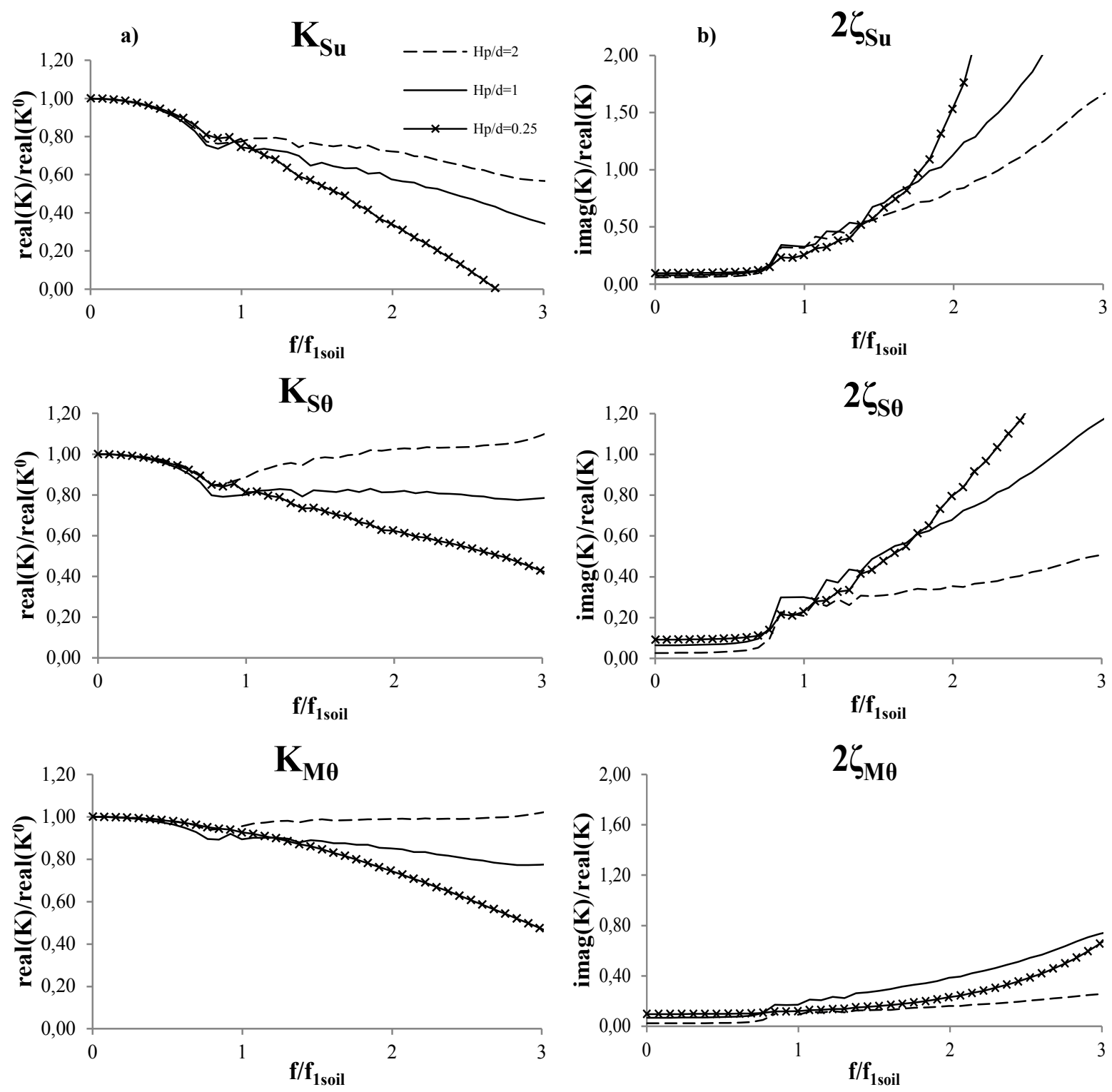

Figure 13: Variation of the three dynamic stiffness and damping coefficients with respect to the nondimensional frequency. Effect of the slenderness ratio in the inhomogeneous soil layer (profile $\mathrm{C}$ ) on the real component (a) and the imaginary component (b). 

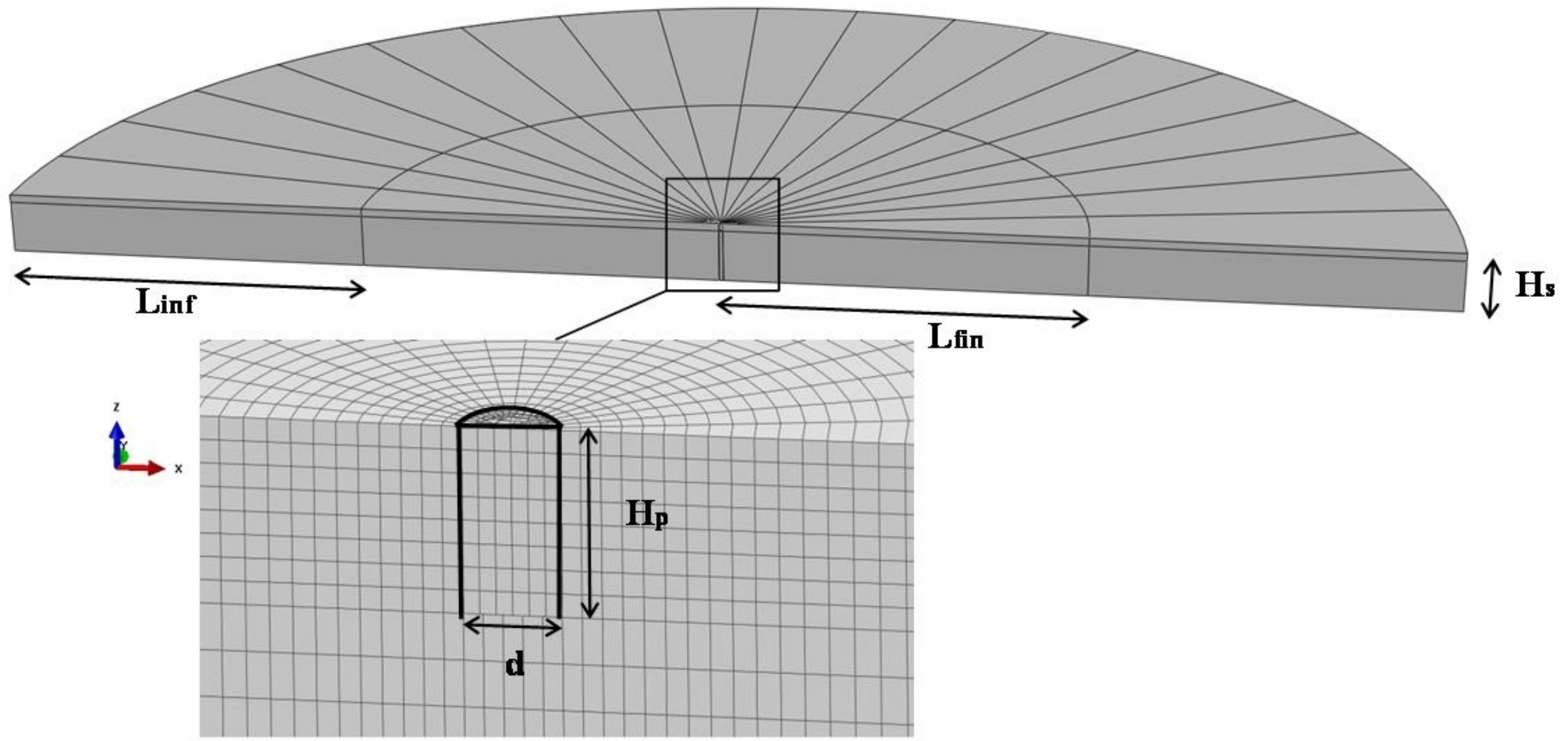
A

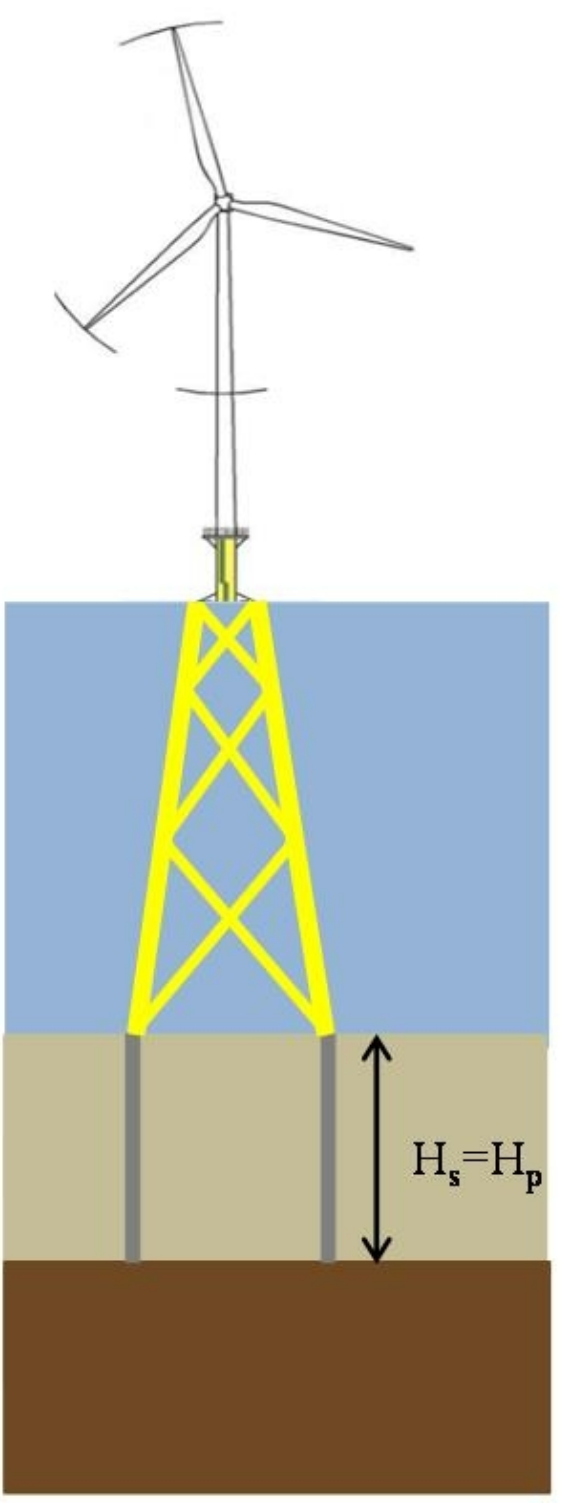

B

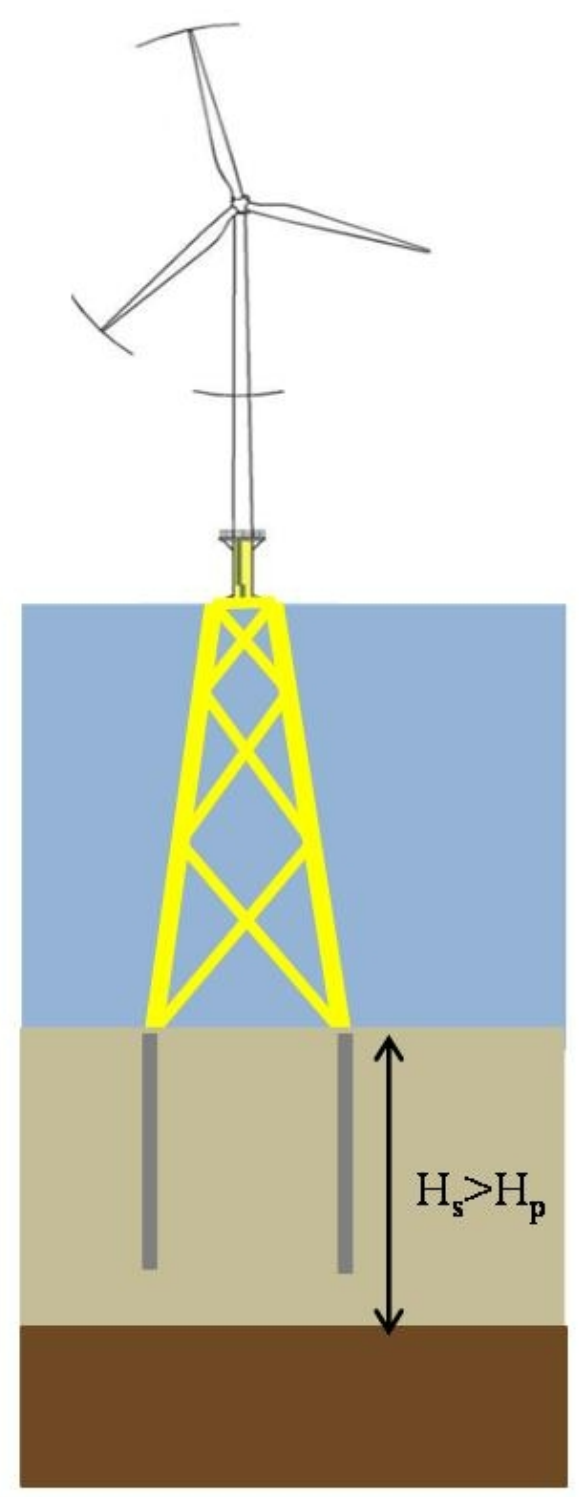

C

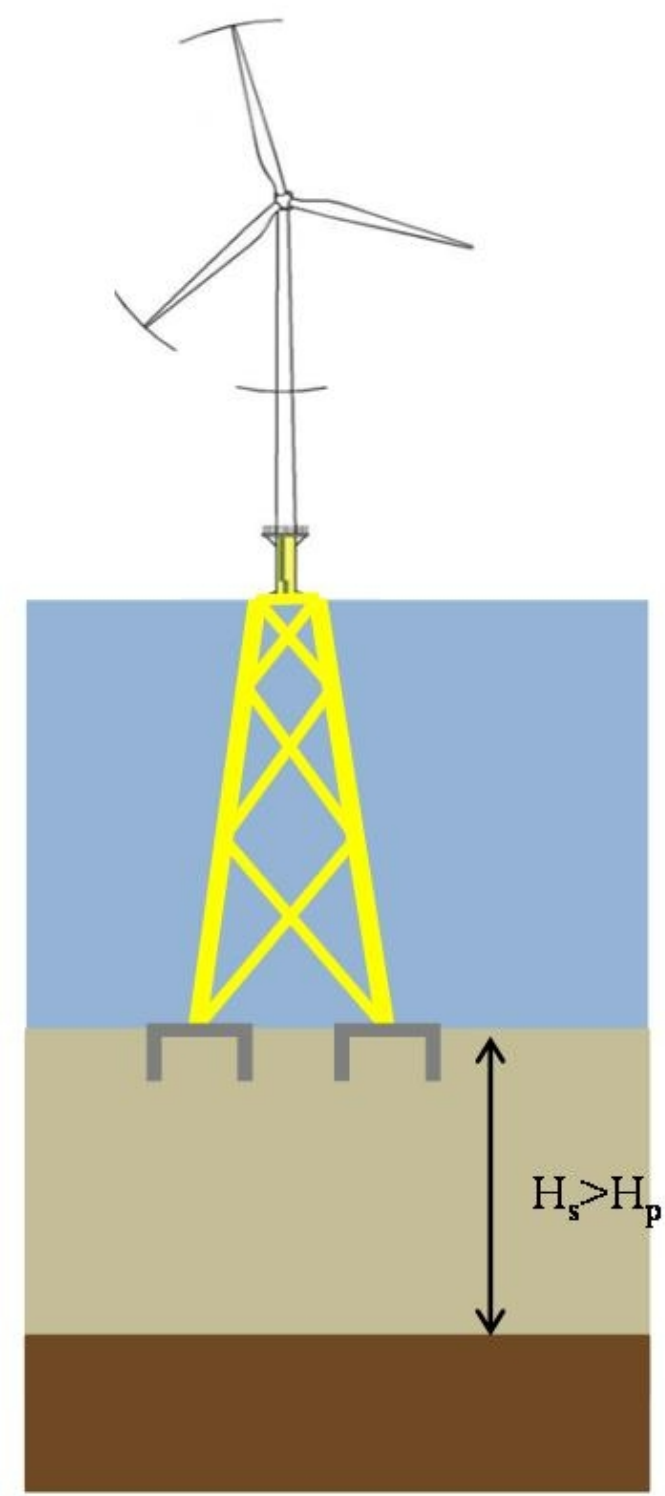



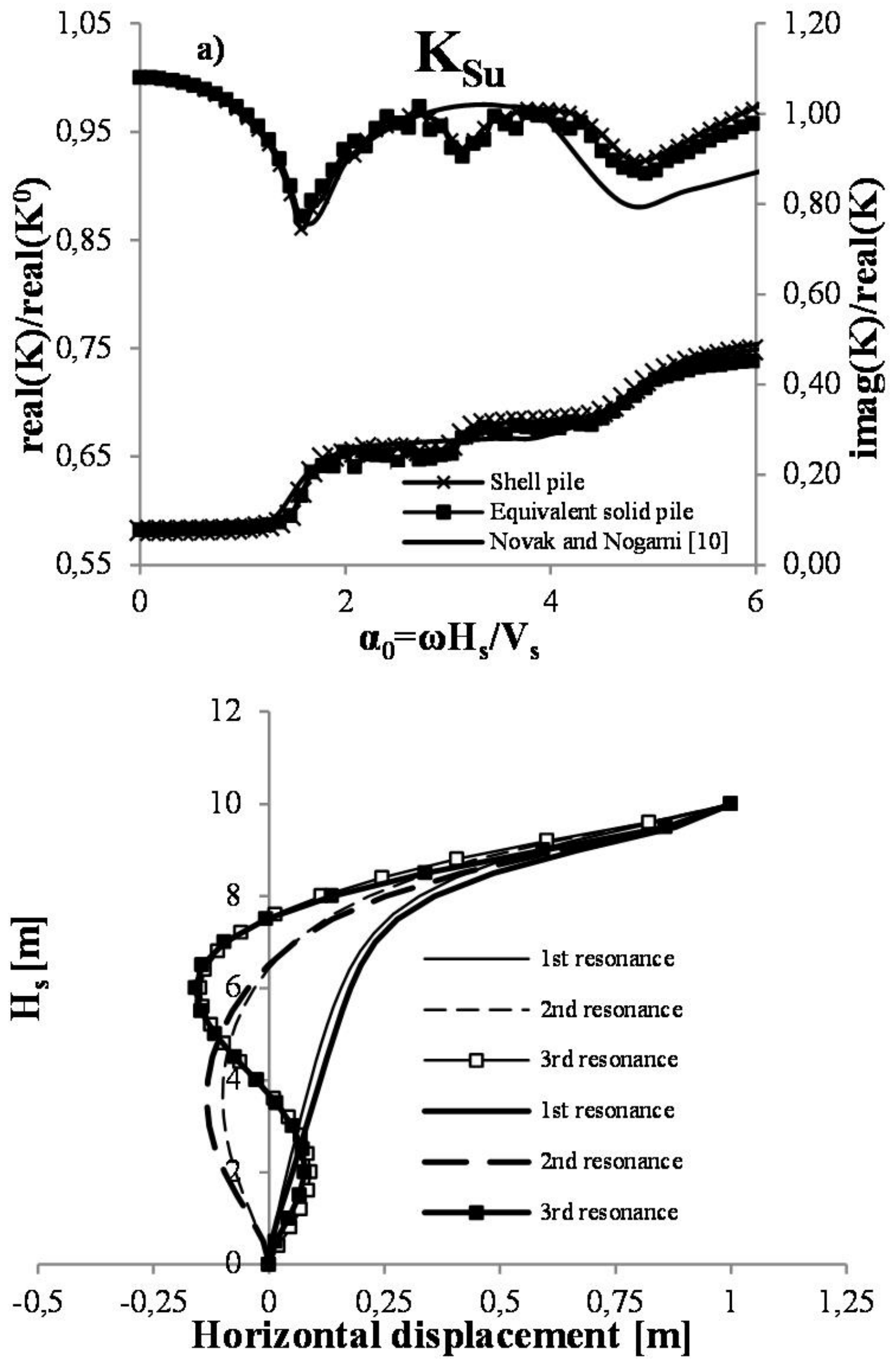

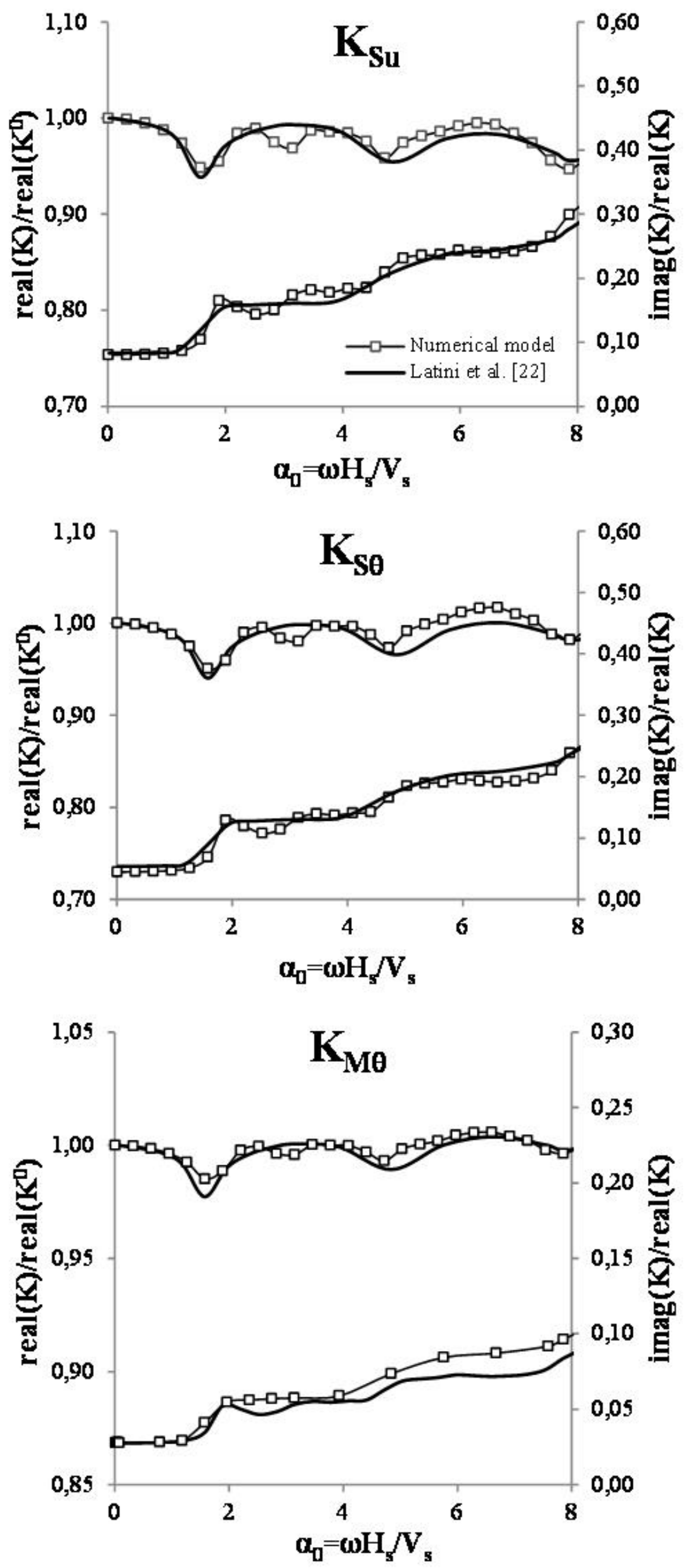


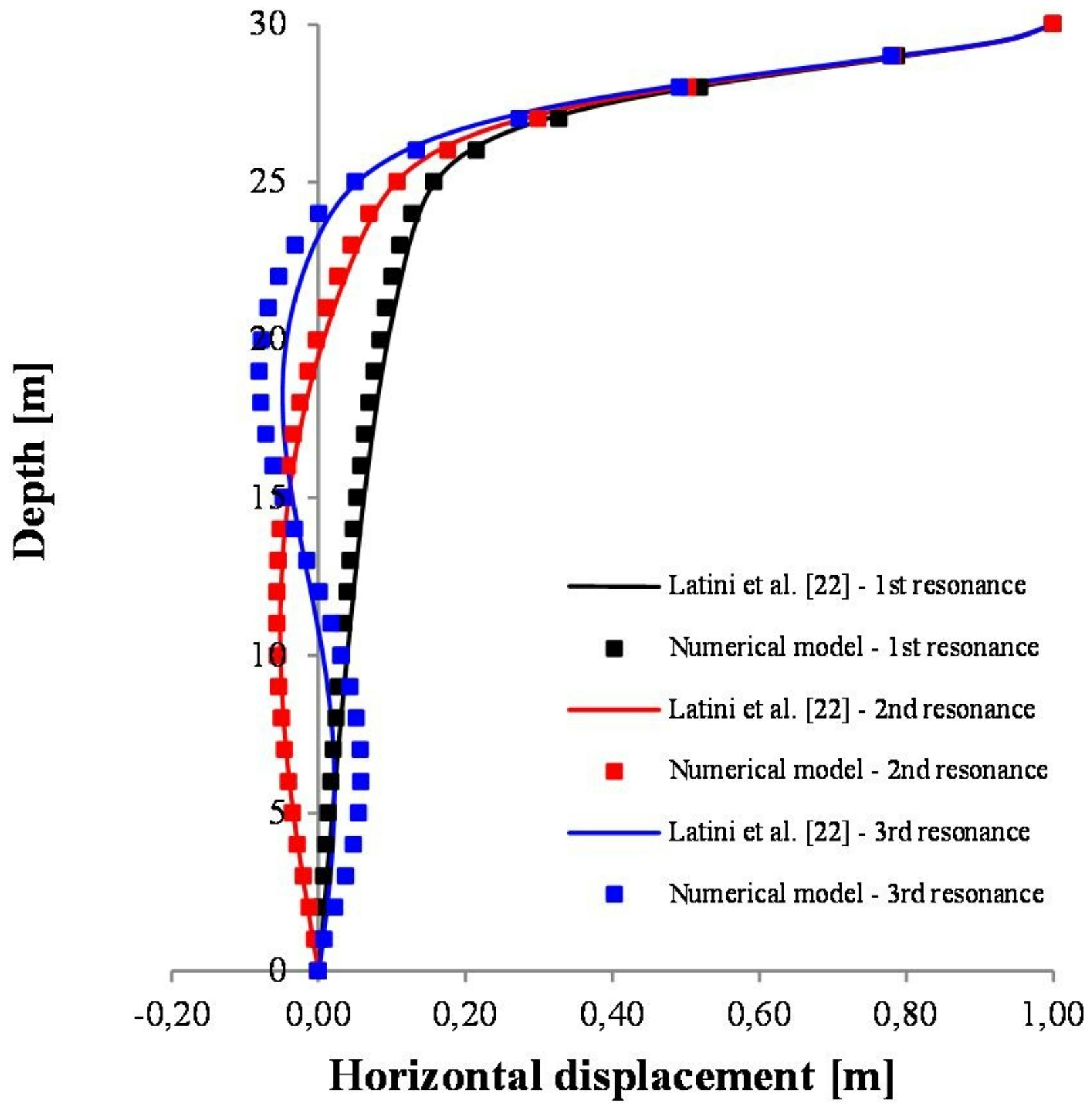




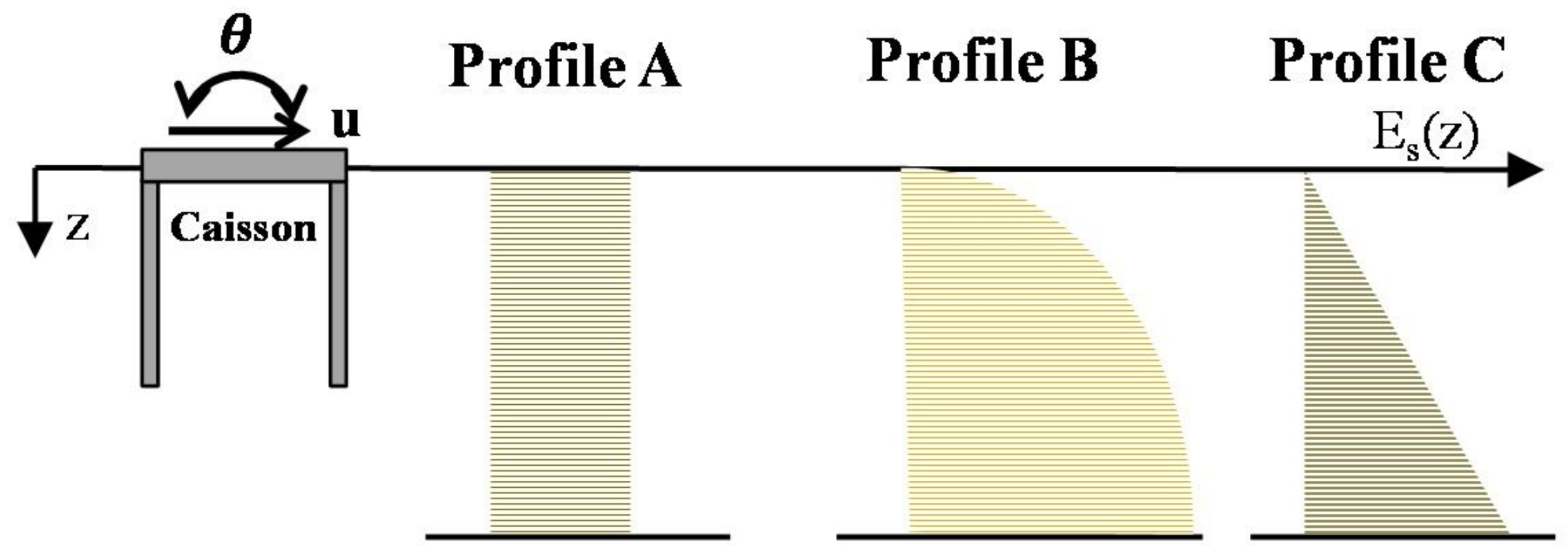



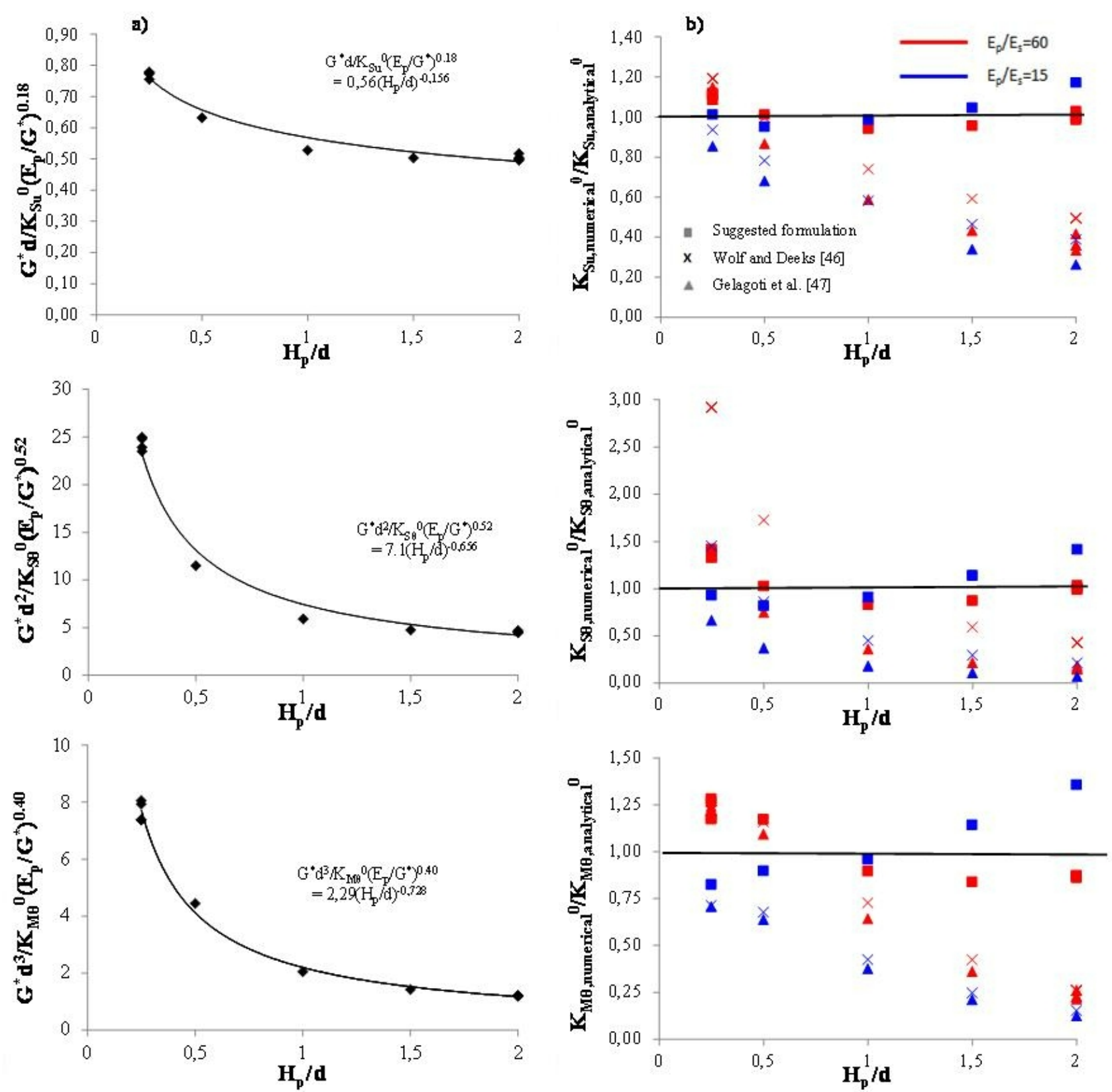

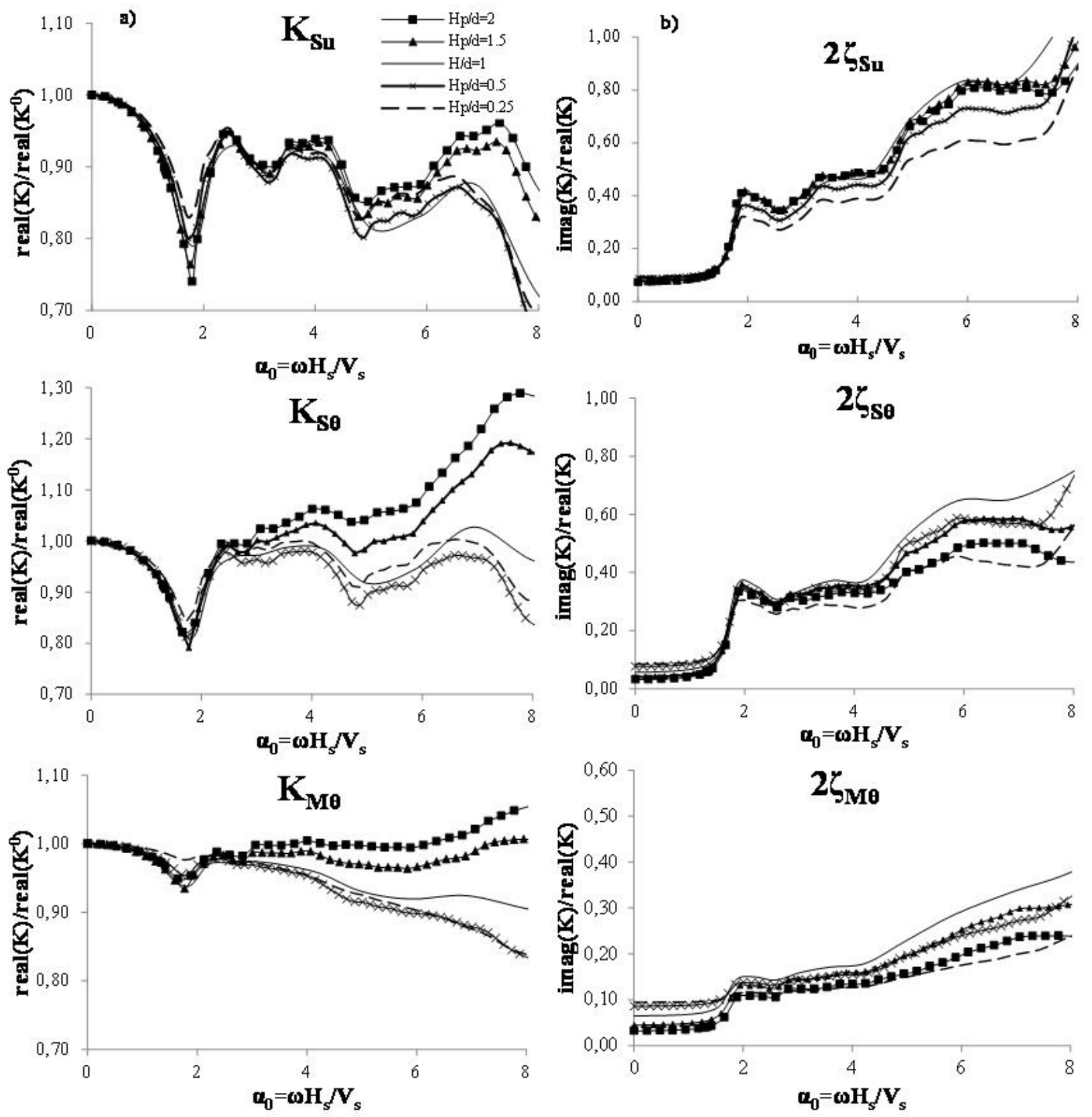

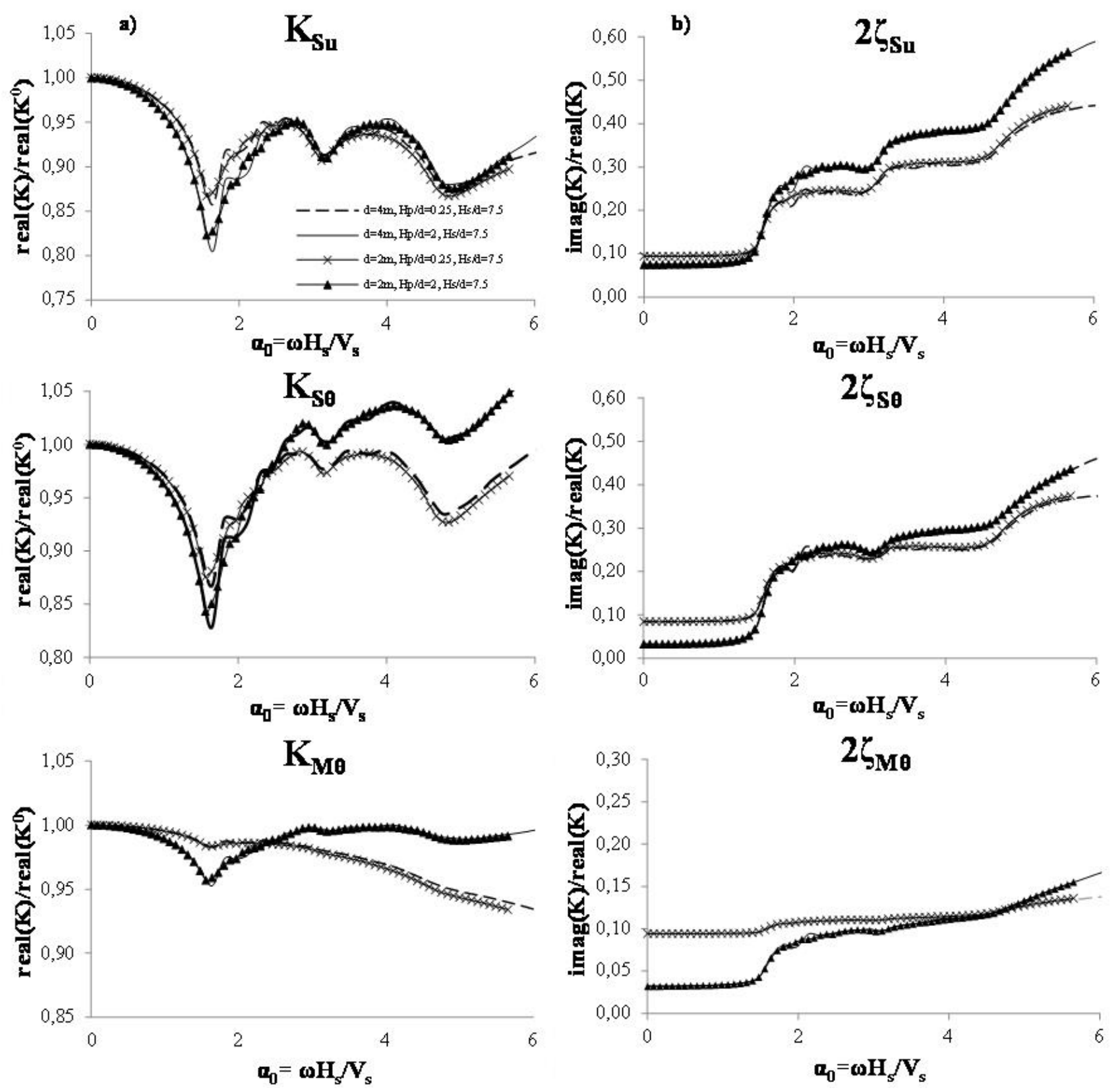

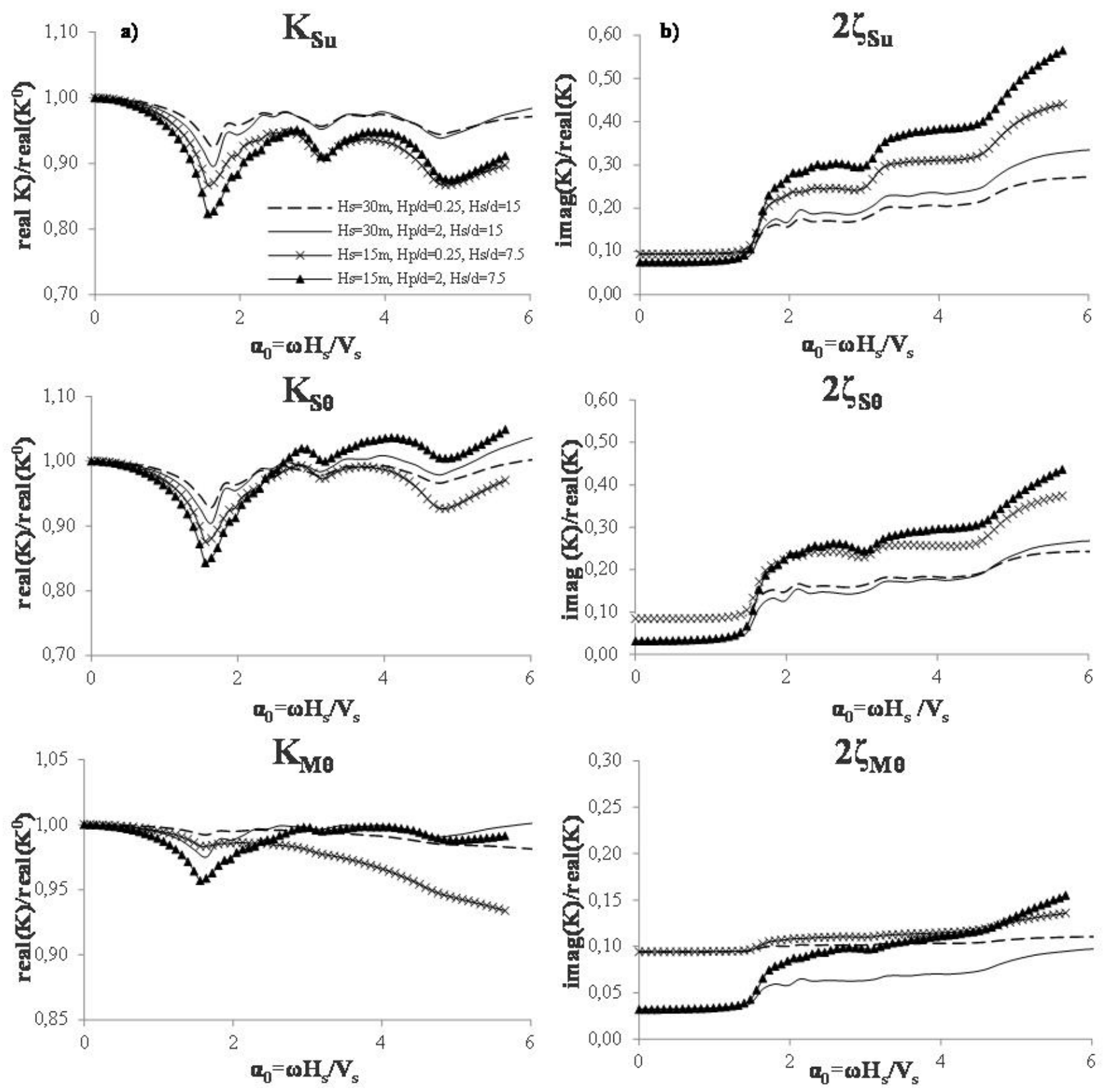

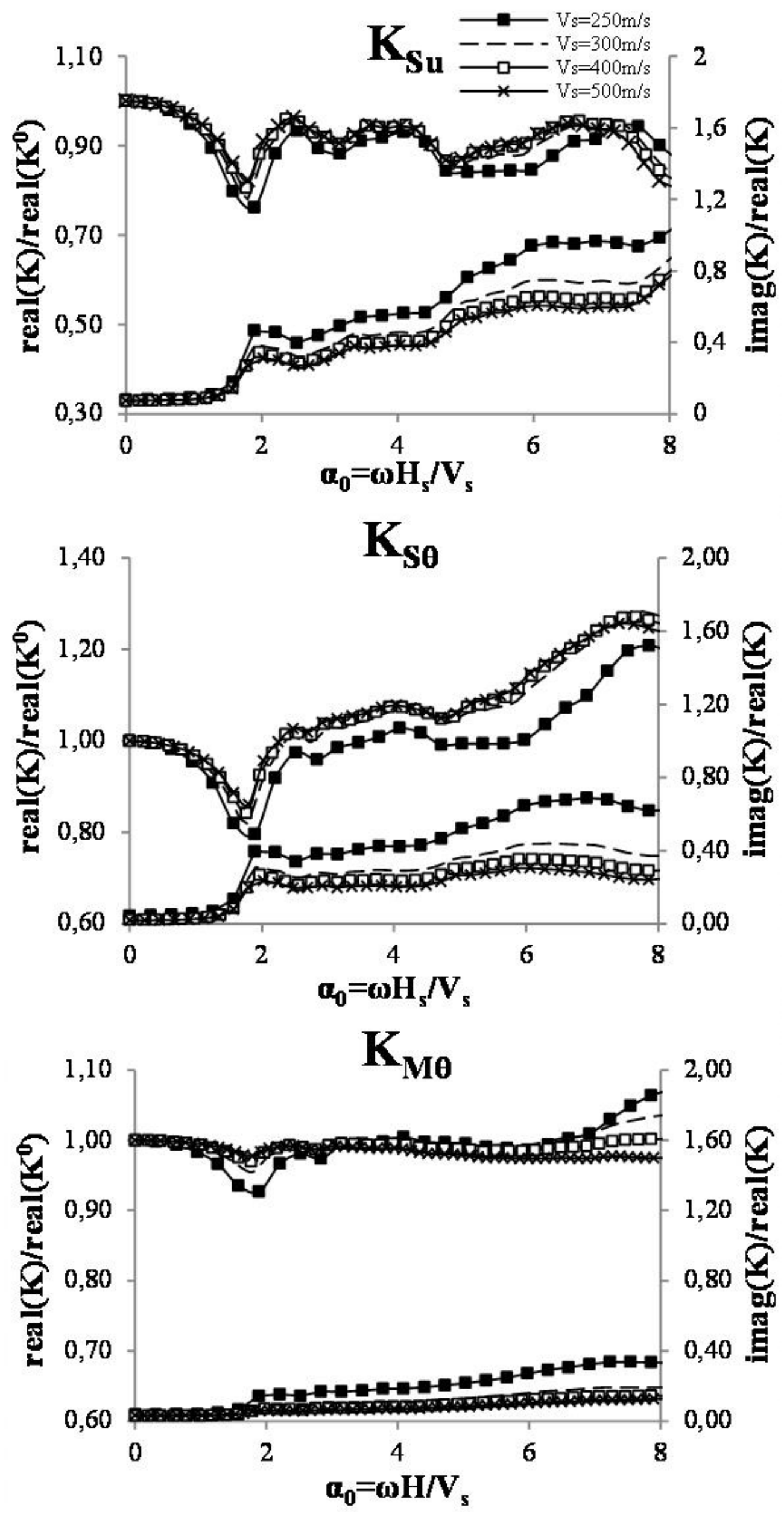

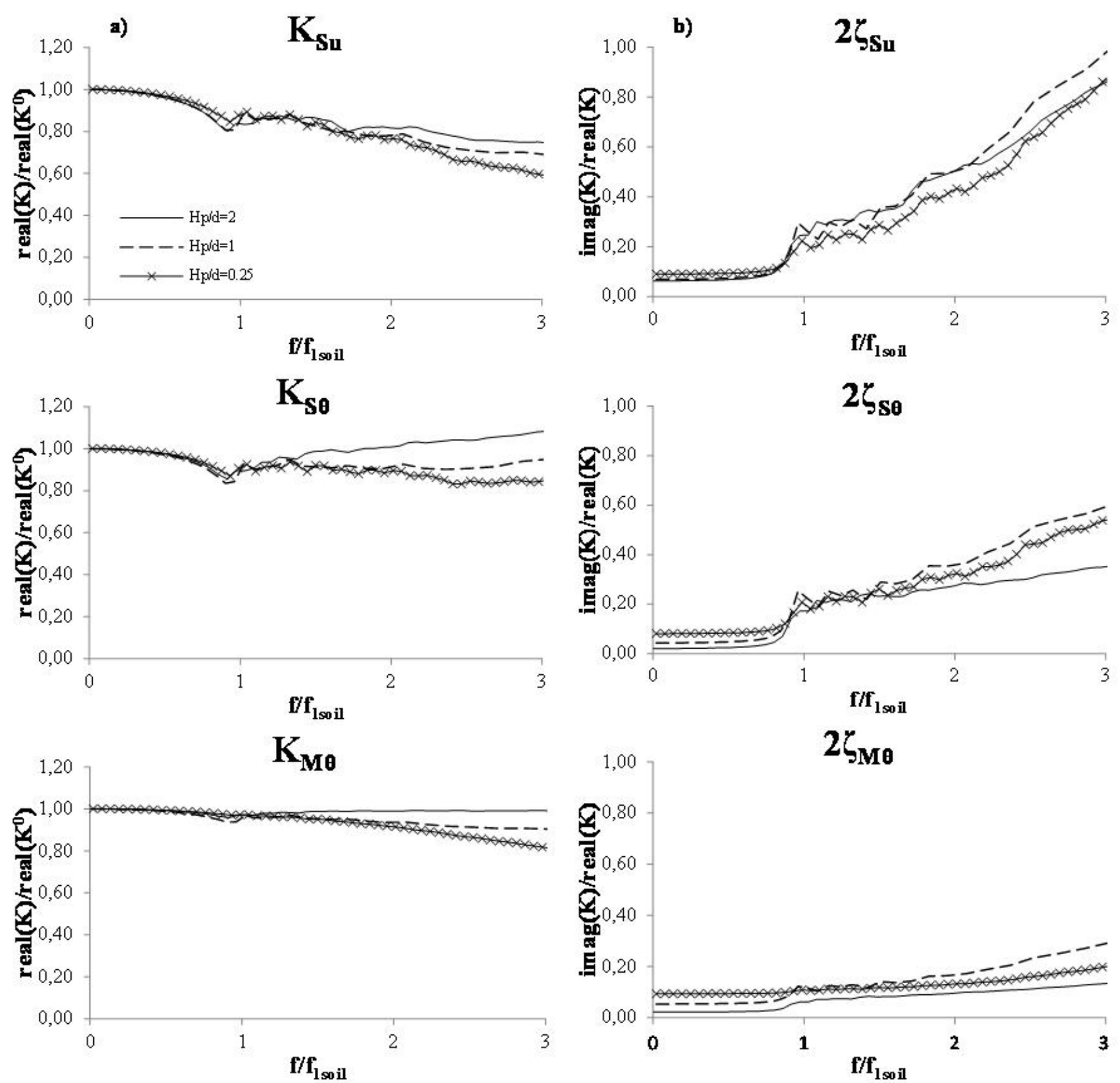

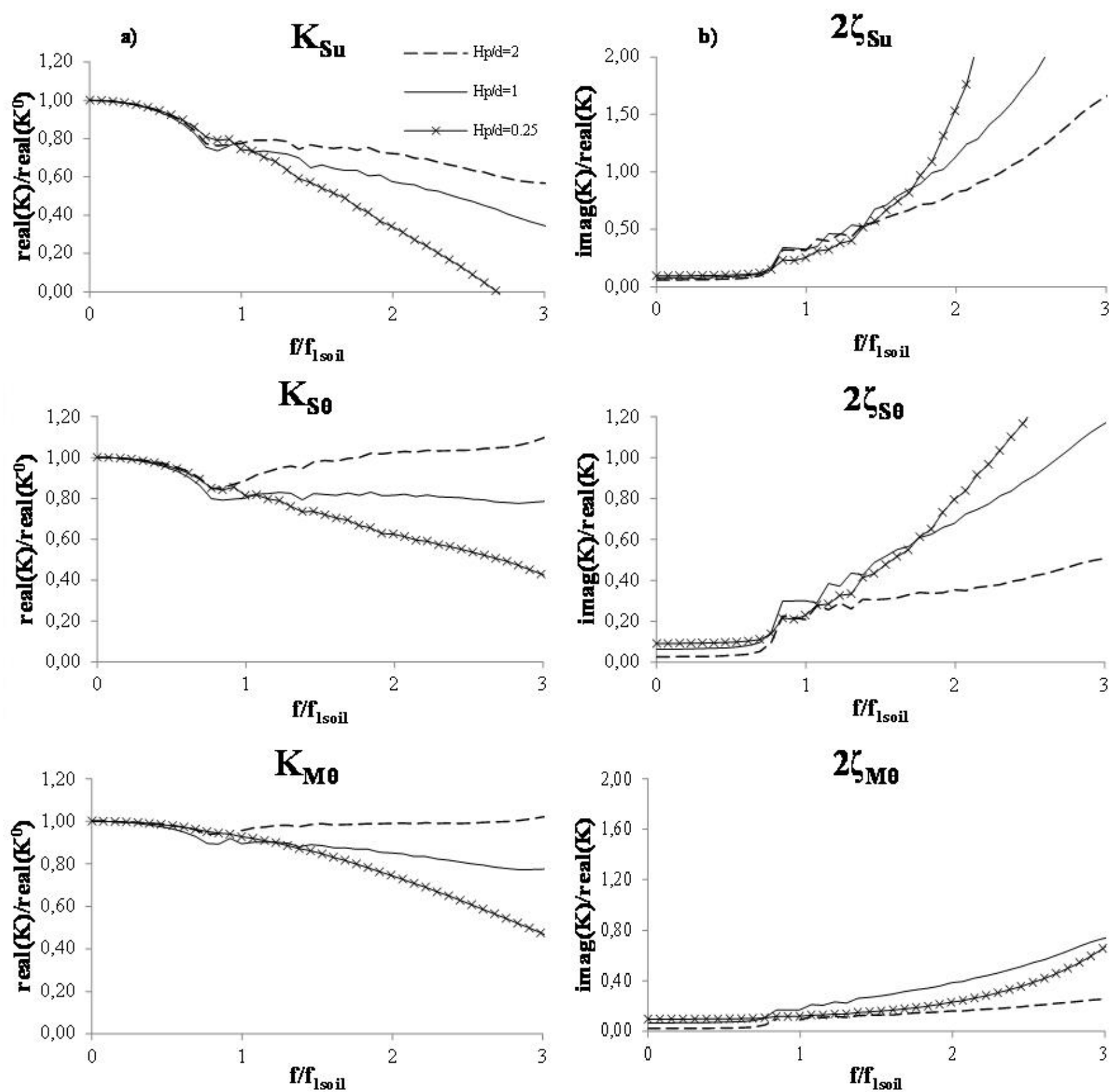
- New expressions for the static stiffness coefficients of suction caissons

- Definition of the dimensionless parameters of dynamic response of suction caissons

- Effect of the slenderness ratio on coupling impedances

- Importance of the relative thickness of the soil layer on the dynamic impedances

- Governing influence of soil stiffness variation with depth on the dynamic impedances 